\title{
A abordagem CTSA nos anos iniciais do ensino fundamental: contribuiçōes para o exercício da cidadania
}

Sandra Godoi Maestrelli*, Leonir Lorenzetti ${ }^{\star *}$

\section{Resumo}

Com o objetivo de tornar o ensino de Ciências mais significativo para a vida dos alunos e contemplar aspectos amplos, como a formação cidadã e as relações entre a ciência, a tecnologia, a sociedade e o ambiente, preconiza-se uma abordagem de ensino que tem como foco o desenvolvimento das inter-relações entre esses elementos. Portanto, o intuito deste artigo é apresentar os resultados de um estudo que analisou como a abordagem CTSA, desenvolvida por meio de uma sequência didática, pode contribuir para o desenvolvimento de conhecimentos, valores, atitudes e habilidades. A sequência didática foi desenvolvida com 24 alunos de uma escola municipal em Araucária-PR, caracterizando-se como uma pesquisa de intervenção pedagógica de natureza qualitativa. Os dados apontam que a proposta de ensino permitiu aos alunos participar ativamente do processo de construção do conhecimento. Por meio das discussões, foram desenvolvidos conhecimentos, valores, atitudes e habilidades que são elementos essenciais para o exercício da cidadania.

Palavras-chave: Ensino de Ciências, Sequência didática, Abordagem CTSA, Cidadania.

\section{Introdução}

O conhecimento científico e tecnológico sobre a sociedade e o ambiente tornou-se mais relevante em meados do século XX, a medida que as influências de diversas inovações científicas e tecnológicas se intensificaram. Essa época contribuiu para

\footnotetext{
* Mestre em Educação Científica pelo Programa de Pós-Graduação em Educação em Ciências e em Matemática da Universidade Federal do Paraná. Professora da Rede Pública Municipal de Araucária e Curitiba, Brasil. E-mail: sandramaestrelli04@gmail.com

* Doutor em Educação Científica e Tecnológica pela Universidade Federal de Santa Catarina. Professor do Departamento de Química e do Programa de Pós-Graduação em Educação em Ciências e em Matemática da Universidade Federal do Paraná, Brasil. E-mail: leonirlorenzetti22@gmail.com
} 
significativas mudanças sociais que transformaram, inclusive, as relações pessoais, trazendo também muitas incertezas, especialmente no que se refere à própria condição humana. Tais incertezas continuam se estendendo pelo século XXI, especialmente devido ao período singular vivido atualmente.

Percebe-se que a ciência, apesar de ser uma prática social e histórica, é constantemente negada e desafiada por pós-verdades, um fenômeno que engloba experiências pessoais, preconceitos, opiniões e crenças que são cada vez mais impulsionadas pelas mídias sociais. Estes fatos demonstram a falta de qualidade na alfabetização científica, a falta de promoção de uma ciência cidadã, bem como a comunicação ineficiente do trabalho dos cientistas à sociedade. Em contrapartida, não há como ignorar o fato de que os ataques à ciência também partem de grupos estratégicos e letrados que satisfazem as demandas de uma determinada agenda política e mercadológica (SILVA; VIDEIRA, 2020).

Estas transformações afetam consideravelmente as práticas educativas e o contexto educacional brasileiro como um todo, revelando a necessidade de desenvolver estratégias de ensino com base numa concepção crítica e humanista de educação, que leve os alunos a um processo de aprendizagem que vise questionar a realidade que está posta em seus diversos aspectos, postura que contribui significativamente para uma formação cidadã.

Nessa perspectiva, não é possível pensar no ensino de Ciências Naturais como algo preparatório, direcionado somente para um futuro distante. O aluno não é cidadão do futuro, já é cidadão hoje, por isso, é necessário aprender Ciência para ampliar, no presente, a possibilidade de participação social e desenvolvimento mental de modo a viabilizar a capacidade plena de exercício da cidadania (BRASIL, 1997b).

Dessa forma, é uma tarefa e um desafio da educação proporcionar um ensino de Ciências que se preocupe com as outras dimensões do saber, para além dos conteúdos meramente conceituais. O ensino de ciências é muito importante, mas, somente ensinar conceitos, fatos e princípios não são suficientes para fazer com que alguém reflita sobre suas atitudes, escolhas e decisões.

Neste trabalho adotou-se uma concepção ampla de cidadania, que considera o cidadão que se pretende formar e o modelo de sociedade em que o mesmo está inserido. Nesta perspectiva, a formação cidadã é voltada para o processo de tomada de decisões para uma ação responsável. Com isso, os discentes constituem-se como importantes agentes de transformação da sociedade. É preciso desenvolver valores, 
atitudes e habilidades para que os indivíduos possam ser capazes de intervir na sociedade da qual fazem parte.

Esse conjunto de elementos desempenha um importante papel no processo de constituição do sujeito, e, portanto, pode ser entendido como um objetivo a se atingir na educação. Os valores auxiliam na orientação das condutas das pessoas, ou seja, são princípios normativos que regem a vida dos indivíduos. Segundo o Tema Transversal Ética, uma educação escolar, comprometida com formação de cidadãos, demanda práticas educacionais que estejam voltadas para a compreensão da realidade social, dos direitos e das responsabilidades em relação à vida pessoal, coletiva e ambiental (BRASIL, 1997a).

Os conhecimentos científicos podem ser entendidos como uma construção humana repleta de sentidos e significados, que englobam conceitos e ideias científicas, aspectos da natureza da ciência e as relações entre a ciência, a tecnologia, a sociedade e o ambiente. De acordo com os PCN de Ciências Naturais, a Ciência é um conhecimento que colabora para a compreensão do mundo e suas transformações, e para o reconhecimento do homem como parte do universo e como indivíduo. Neste sentido, o conhecimento científico pode ser definido como um conjunto de atividades humanas, de caráter histórico e, portanto, não neutras (BRASIL, 1997b).

As atitudes estão relacionadas ao desenvolvimento de condutas ou de posturas das pessoas e podem englobar diversos elementos humanos, como os valores e conhecimentos. No ensino de Ciências Naturais as atitudes estão relacionadas com o desenvolvimento de posturas na relação entre o homem, o conhecimento e o ambiente (BRASIL, 1997b).

As habilidades, por sua vez, são o conjunto de capacidades próprias do ser humano que permitem o 'fazer científico'. O desenvolvimento das habilidades demanda a participação ativa dos alunos numa série de atividades como a busca de informações que podem ser utilizadas para resolução de problemas reais, o interesse pelos temas abordados e o uso da expressão para exercitar direitos e deveres.

Auler (2007) destaca que, o 'aprender das crianças' deve ser direcionado para a participação, pois é na aprendizagem que ocorre a participação no processo de busca de respostas, de encaminhamentos para os problemas que se apresentam na sala de aula, na procura de solução para as situações colocadas pelo professor e na reinterpretação e ressignificação das experiências vividas. Portanto, não há como 
formar um sujeito participante e autônomo somente falando sobre autonomia e democracia, é preciso exercitar tais capacidades.

De acordo com Santos (2007) é nesse cenário que surge a abordagem de ensino CTSA, com a discussão de temáticas que proporcionem a reflexão e a resolução de problemas sobre as consequências ambientais do desenvolvimento científico e tecnológico.

Embora muitos utilizem o argumento de que a temática ambiental já está contemplada nos estudos CTS, esta mesma alegação poderia ser utilizada para questionar também o estudo da ciência, da tecnologia e da sociedade, uma vez que todas as relações inerentes à abordagem CTS, educação CTS, perspectiva CTS são próprias da atividade científica, de modo que seria suficiente tratá-las apenas pela educação científica (VILCHES; PÉREZ; PRAIA, 2011; FERST, 2013).

Neste trabalho, a opção por adicionar a letra ' $A$ ' de ambiente ao final da sigla CTS, objetivou enfatizar as consequências ambientais dos desenvolvimentos científicos e tecnológicos. É importante ressaltar que os pesquisadores que promovem o uso da expressão CTSA não estão dizendo que o 'A' não está contido na sigla CTS e, muito menos, que as questões ambientais não eram abordadas anteriormente, pois se entende que não é possível desvincular essas questões quando se estuda as relações CTS, mas, sim, que a educação científica havia incorrido em reducionismos que deixavam de lado a questão ambiental (VILCHES; PÉREZ; PRAIA, 2011; FERST, 2013).

É preciso reconhecer que a vinculação dos estudos CTS com o movimento ambientalista é legitimada em textos clássicos sobre o assunto e evidenciada por diversos autores e pesquisadores como Glen S. Aikenhead, Ermínia Pedretti, Amparo Vilches e Daniel Gil Pérez, que utilizam o termo CTSA desde a década de 1990. Estes autores expressam uma preocupação com o desenvolvimento de ações que sejam comprometidas com a problemática socioambiental (SANTOS, 2011).

Invernizzi e Fraga (2007) concordam que a dimensão ambiental parece ter sido um dos tópicos fundantes dos estudos CTS e ressaltam que a inserção da letra ' $A$ ' à sigla CTS destaca a importância crescente que a perspectiva socioambiental vem adquirindo nos sistemas de ensino por meio da educação ambiental (EA).

A questão ambiental é uma preocupação cada vez mais presente em nossa sociedade e é uma realidade com a qual o ser humano precisa aprender a conviver. Isso implica na necessidade de um ensino voltado para a temática do meio ambiente, 
contribuindo para a formação de sujeitos críticos que busquem a preservação da vida do planeta e melhores condições sociais para a existência humana (VASCONCELLOS; SANTOS, 2007).

Martins e Paixão (2011) esclarecem que a orientação CTS permite um ensino contextualizado a partir da abordagem de problemas atuais, bem como suas variáveis e valores. Esse corpo de saberes deverá ser um instrumento a serviço da compreensão sobre o mundo.

Durante os últimos séculos, o ser humano foi considerado o centro do universo. $\mathrm{O}$ homem acreditou que a natureza estava à sua disposição e se apropriou de seus processos, alterando seus ciclos e modificando seus espaços. O ser humano contribuiu para uma grave situação de emergência planetária caracterizada por um conjunto de problemas como contaminação, esgotamento e destruição de recursos naturais, urbanização acelerada e desordenada do planeta, degradação generalizada dos ecossistemas, desigualdade social e conflitos de todos os tipos (BRASIL, 1997b; VILCHES; PÉREZ; PRAIA, 2011).

Seguindo essa tendência, o desenvolvimento científico e tecnológico foi visto durante muito tempo de forma neutra e determinista. Havia um entendimento completamente ingênuo de que a ciência e a tecnologia não expressavam valores, interesses e ideologias das sociedades e dos grupos que as geravam. Sendo assim, elas seriam capazes de resolver todos os problemas, inclusive os ambientais. Esta ideia linear até hoje suscita discussões de que os problemas ambientais de países capitalistas, como o Brasil, poderiam ser resolvidos apenas com maior investimento em Ciência e Tecnologia (VON LINSINGEN; PEREIRA; BAZZO, 2003; NOVAES; FRAGA, 2010).

Nesse sentido, por se tratar de uma educação ambiental crítica para a formação da cidadania, o fundamento da relação com o meio ambiente deve possuir uma ordem ética, já que a origem de muitos problemas ambientais pode estar no comportamento da própria sociedade. Sendo assim, em vez do padrão comportamental mantido por meio de uma educação escolar normativa, rotineira e reprodutiva, a atuação pedagógica deve se pautar no desenvolvimento de uma nova mentalidade, uma nova ética e uma nova práxis que envolva um conjunto de conhecimentos, valores, atitudes e habilidades, visando contribuir para modificar a realidade.

O compromisso de uma educação voltada para o exercício da cidadania exige uma prática educacional direcionada para a compreensão da realidade social, dos 
direitos, dos deveres e das responsabilidades em relação à vida pessoal, coletiva $\mathrm{e}$ ambiental. A ética pode significar um pensamento reflexivo sobre os valores e normas que regem as condutas humanas. A questão central das preocupações éticas é a da justiça inspirada pelos valores de igualdade, equidade, respeito mútuo, justiça, diálogo e solidariedade (BRASIL, 1997a).

Carvalho (2004) afirma que é preciso recusar tanto a crença individualista de mudança social (que defende que a mudança social só ocorre pela soma das mudanças individuais quando cada um fizer a sua parte) como a crença num sistema social, genérico e despersonalizado, o qual se deve mudar primeiro para somente depois dar lugar às transformações na vida dos grupos sociais. A formação para a cidadania incide sobre as relações do indivíduo e da sociedade e somente fazem sentido se pensados coletivamente.

Santos e Mortimer (2002), ao discutirem sobre os pressupostos de currículos de Ensino de Ciências com ênfase em CTS, apresentam exemplos de orientação curricular e estrutura conceitual. Um deles é o de Bybee (1987), o qual é composto por três elementos: conceitos científicos e tecnológicos, processos de investigação e interações entre ciência, tecnologia e sociedade.

A aquisição de conhecimentos científicos e tecnológicos enfatizaria aspectos relacionados ao interesse pessoal, à preocupação cívica e às perspectivas culturais. Os processos de investigação científica e tecnológica propiciariam a participação ativa dos alunos na obtenção de informações, solução de problemas e tomada de decisão. A interação entre ciência, tecnologia e sociedade propiciaria o desenvolvimento de valores e ideias por meio de estudos de temas locais, políticas públicas e temas globais (SANTOS; MORTIMER, 2002, p. 115).

Na perspectiva da abordagem CTSA, esses elementos podem ser ampliados, inserindo-se a aquisição de conhecimentos ambientais, numa abordagem ampla que considere os aspectos sociais, éticos, culturais, políticos e econômicos.

O estudo de Maestrelli e Lorenzetti (2017) analisou a produção acadêmica sobre as relações CTSA nos anos iniciais disseminados no Encontro Nacional de Pesquisa em Educação em Ciências (ENPEC), bem como a forma como os livros didáticos abordam as inter-relações entre Ciência, Tecnologia, Sociedade e Ambiente.

Apesar de ainda ser incipiente, é possível identificar um conjunto de dissertações e teses produzidas no Brasil que abordam a Educação CTS/CTSA nos anos iniciais. Dentre os trabalhos podemos destacar os estudos de Ferst (2016), Fabri 
(2011, 2017), Ferreira (2016), Oliveira (2017), Mota (2017), Rodrigues (2017) e Viecheneski (2013, 2019).

Portanto, a partir da emergência desses estudos e com base na reflexão sobre tais necessidades, apresenta-se neste trabalho, como a abordagem CTSA, desenvolvida por meio de uma sequência didática, pode contribuir para o desenvolvimento de conhecimentos, valores, atitudes e habilidades nas aulas de ciências nos anos iniciais.

\section{Aspectos metodológicos}

O estudo caracterizou-se como uma pesquisa de intervenção pedagógica. Segundo Damiani et al. (2013) as pesquisas de intervenção pedagógica têm o intuito de produzir mudanças, a tentativa de resolver problemas, o caráter aplicado, a necessidade de dialogar com o referencial teórico e a possibilidade de produzir conhecimento.

A pesquisa de intervenção pedagógica insere-se no campo das pesquisas aplicadas, caracterizando-se pelos seguintes aspectos:

1) são pesquisas aplicadas, em contraposição a pesquisas fundamentais; 2) partem de uma intenção de mudança ou inovação, constituindo-se, então, em práticas a serem analisadas; 3 ) trabalham com dados criados, em contraposição a dados já existentes, que são simplesmente coletados; 4) envolvem uma avaliação rigorosa e sistemática dos efeitos de tais práticas, isto é, uma avaliação apoiada em métodos científicos, em contraposição às simples descrições dos efeitos de práticas que visam a mudança ou inovação (DAMIANI, 2012, p. 7).

A instituição de ensino escolhida para a intervenção está localizada na região metropolitana de Curitiba, no município de Araucária, estado do Paraná. Destaca-se que a escolha da referida instituição se deu em função do trabalho de um dos autores exercia atividade docente nesta escola, como profissional de apoio.

Com relação aos conteúdos relativos ao trimestre letivo, optou-se por trabalhar com uma turma de $4 \square$ ano do ensino fundamental. Após análise realizada em vários documentos, incluindo o referencial teórico deste trabalho e o plano curricular do município de Araucária, constatou-se que os conteúdos sobre água apresentavam maior potencial para o desenvolvimento da abordagem CTSA, devido à sua organização no bloco de educação ambiental.

A classe era composta por 24 estudantes, sendo 15 meninas e 9 meninos. Um destes estudantes era aluno de inclusão, pessoa com Transtorno do Espectro Autista (TEA). Quanto à faixa etária 18 alunos tinham 8 anos, 1 estudante tinha 9 anos, 2 tinham 10 
anos e 3 estudantes tinham 11 anos. De modo geral, era uma turma comunicativa e entrosada, pois a professora regente vinha acompanhando-os desde $03 \square$ ano do ensino fundamental, fato que fortaleceu os vínculos e o convívio social do grupo. Para manter a identidade dos sujeitos da pesquisa em sigilo foram criados códigos para os alunos e a professora, sendo que a docente foi representada pela sigla P1 e os estudantes pelo símbolo A, seguido de uma numeração específica. As aulas da sequência didática foram representadas pela letra $\mathrm{E}$, seguida pela numeração de ordem cronológica.

A investigação compreendeu, inicialmente, a realização do programa de formação. Com o objetivo de dar início ao curso, solicitamos à direção da escola e à pedagoga responsável pelas turmas do $4 \square$ ano, que convidassem todas as docentes destas turmas, dos períodos da manhã e tarde, para uma reunião de divulgação do programa de formação. Todas as professoras compareceram, porém, apenas duas docentes aceitaram participar da formação. Uma das professoras que já é graduada em Educação em Ciências e em Matemática ficou interessada em aprender mais sobre a sua área de formação. A outra docente, que é graduada em Pedagogia, não possui muita experiência com a disciplina de ciências, e, por isto, resolveu participar do curso. Nesta reunião também foram apresentados mais detalhes sobre o curso de formação e o tipo de pesquisa que seria desenvolvido, mediante a aprovação pelo Comitê de Ética, além da disciplina e o período letivo.

Como as professoras trabalhavam em períodos diferentes, foi necessário estabelecer um acordo entre as partes. Ficou combinado que os encontros de formação ocorreriam na própria escola, em três segundas-feiras do mês de setembro do ano de 2016, no dia de hora-atividade das docentes. No entanto, para que fosse possível a participação das duas profissionais ao mesmo tempo, uma das docentes aceitou vir somente no período da tarde, no contraturno do seu horário de expediente, fato que mostra o envolvimento e o interesse de ambas em participar do estudo. Este empenho também foi notado pela gestão da escola, que ofereceu dias de folga relativos aos dias de formação para que as profissionais que aceitaram participar da pesquisa não ficassem sem o momento de planejamento de suas aulas.

O programa de formação foi destinado exclusivamente às duas professoras do $4^{\circ}$ ano e, a pedido da equipe de gestão escolar, foi acompanhado pela diretora, vice-diretora e pedagoga responsável pelas turmas. O objetivo do curso foi oferecer os elementos necessários para desenvolver e implementar uma sequência didática com o tema socioambiental - água - a partir dos pressupostos da abordagem CTSAe dos 
mapas conceituais, com a utilização da metodologia dos Três Momentos Pedagógicos (3MP). Por se tratar de um programa composto de estudos presenciais e a distância, as professoras foram avisadas que alguns textos com temas relativos aos encontros seriam enviados antecipadamente para a leitura prévia.

O primeiro encontro do Programa de Formação ocorreu no dia 05 de setembro de 2016, no período das 13 às 17 horas, num espaço anexo à sala de planejamentos da escola e contou com a presença da diretora da instituição, da vice-diretora, da pedagoga das turmas do $4 \square$ ano e das duas professoras participantes, além das pesquisadoras, e do professor orientador que foram responsáveis por conduzir as discussões. As palestras compreenderam as temáticas: ensino de Ciências nos anos iniciais do ensino fundamental e a abordagem de ensino Ciência, Tecnologia, Sociedade e Ambiente (CTSA). A exposição dos assuntos foi realizada no formato de palestra, com a utilização de projetor de imagens.

O segundo encontro ocorreu no dia 19 de setembro de 2016, no período das 13 às 17 horas, no mesmo local anteriormente utilizado e contemplou estudos teóricos e práticos sobre a temática dos mapas conceituais e a metodologia dos três momentos pedagógicos. Participaram da formação, a pedagoga das turmas do $4 \square$ ano, as duas professoras participantes da pesquisa, além das pesquisadoras, que nesse dia foram as responsáveis por ministrar os conteúdos. O curso foi estruturado em dois momentos: teórico e prático. O primeiro momento de estudos teóricos objetivou abordar o tema geral e suas definições e foi realizado em formato de palestra. $\mathrm{O}$ segundo momento contemplou uma formação prática com a realização de mapas conceituais pelas docentes participantes da pesquisa. Esta formação foi necessária já que os mapas conceituais serão utilizados nas aulas da sequência didática como recursos didáticos diferenciados.

O terceiro e último encontro foi realizado no dia 26 de setembro de 2016 , no período das 13 às 17 horas, no mesmo local e contou com a discussão de aspectos relativos à estruturação e aplicação da sequência didática. A tarde de curso foi organizada em dois momentos: apresentação, leitura e discussão do texto sobre os 3MP e, posteriormente, a apresentação, leitura e discussão da sequência didática. Neste momento optou-se por não utilizar projetor de imagens, apenas foram entregues cópias do texto e da sequência didática para cada um dos participantes. As aulas foram analisadas, revistas, discutidas e aprovadas pelas professoras participantes da pesquisa, com base nos conhecimentos que foram discutidos nos encontros. As 
docentes demonstraram interesse e participaram ativamente das discussões, inclusive sugerindo algumas modificações que foram acatadas.

A proposta didática foi previamente organizada pela pesquisadora com a abordagem CTSA e os conteúdos relevantes estabelecidos no currículo de Ciências. Para uma abordagem ainda mais efetiva, a sequência didática foi organizada de acordo com o modelo desenvolvido por Aikenhead apud Santos e Mortimer (2002, p. 121122), que segue etapas sequenciais:

(1) introdução de um problema social; (2) análise da tecnologia relacionada ao tema social; (3) estudo do conteúdo científico definido em função do tema social e da tecnologia introduzida; (4) estudo da tecnologia correlata em função do conteúdo apresentado e (5) discussão da questão social original.

Em função da escolha pela abordagem de ensino CTSA e com o intuito de evitar reducionismos, esses elementos foram ampliados com a inserção do estudo das questões ambientais, que foram discutidas na perspectiva de uma sociedade sustentável.

A expressão sociedade sustentável é bastante recente. Ela surgiu em 1990, no contexto do Fórum Brasileiro de Organizações Não Governamentais (ONGs) e Movimentos Sociais para o Meio Ambiente e Desenvolvimento, como uma espécie de preparação para o evento Rio 92. Neste encontro, milhares de pessoas discutiram como seria um 'Brasil diferente' que se desenvolvesse respeitando os princípios básicos dos diferentes tipos de sustentabilidade e da democracia (RATTNER, 2000).

No contexto de uma sociedade sustentável há um constante processo de envolvimento, de entrega e participação sobre o mundo que se deseja. Deste modo, é preciso utilizar uma abordagem sistêmica e global e estar atento aos diversos tipos de sustentabilidade. Por isso, o conceito de sociedade sustentável vai muito além da premissa do desenvolvimento sustentável. Esta escolha ocorreu pela preferência na América Latina, de uma perspectiva crítica de visão socioambiental, a qual evita enxergar a ciência de maneira distorcida, como redentora e salvacionista do velho modelo insustentável de ciência e tecnologia, que tem por base um consumo ilimitado e obsolescência planejada das mercadorias (SANTOS, 2011).

Diegues (1992) defende que a EA sob a ótica de uma sociedade sustentável, é um verdadeiro desafio, algo para se enfrentar ao longo século XXI, porém, após iniciada, poderá oferecer muitas possibilidades de mudança, contribuindo principalmente para que as pessoas passem a se comportar como sujeitos e não meros objetos do desenvolvimento. 
Essa concepção contribui para uma mudança de valores e atitudes, principalmente pela compreensão de que a vida não se dá num mundo não tão amplo e ilimitado como se pensava anteriormente. Nesse sentido, o contexto da atual crise global convida todos a construir outro modelo de EA que rompa com os velhos paradigmas, os quais são movidos pela lógica do consumismo, do lucro, da obsolescência de mercadorias, sem pensar no futuro e nas consequências que estas ações podem trazer ao planeta (SANTOS, 2011).

Nesse sentido, a educação contribui com a formação cidadã, proporcionando processos educativos de qualidade, capazes de sensibilizar o indivíduo e a coletividade para a importância da construção de conhecimentos, valores, atitudes e habilidades, voltados para o contexto de uma sociedade sustentável. Sendo assim, a educação ambiental crítica na perspectiva de sociedades sustentáveis surge como uma alternativa diferenciada quando se pensa o sujeito social e não o modelo de desenvolvimento.

Para oportunizar o entendimento, a sequência didática foi estruturada por meio da metodologia dos três momentos pedagógicos (3MP) que segue os seguintes passos sequenciais: problematização inicial, organização do conhecimento e aplicação do conhecimento. Os 3MP propõem o estabelecimento de uma dinâmica dialógica em sala de aula entre o professor e os alunos, objetivando a construção/reconstrução do conhecimento (DELIZOICOV; ANGOTTI; PERNAMBUCO, 2011).

A sequência didática foi implementada pelas professoras participantes da pesquisa, gravadas em vídeo e observadas pela pesquisadora. As doze aulas foram ministradas em seis semanas, distribuídas em duas aulas de cinquenta minutos, todas as quintas-feiras, no período da manhã, entre os meses de outubro e novembro do ano de 2016.

As duas primeiras aulas trataram da importância da presença da água no solo, no ar e nos organismos vivos. O propósito foi iniciar o estudo sobre a água a fim de verificar se $o$ aluno percebia a presença da mesma em formas diversas, em diferentes locais do ambiente e se reconhecia a interferência do ser humano nas condições desse elemento. No início da aula foi introduzido o seguinte questionamento: Onde podemos encontrar água? Em quais figuras temos a presença de água? Como você sabe que aí tem água? Alguma figura não tem água? Por quê? Estas questões objetivaram identificar as concepções prévias dos alunos em relação à presença de água em todo o planeta, caracterizando a problematização inicial. Na etapa da organiza- 
ção do conhecimento, foram realizadas três atividades. Na primeira, foi realizado um experimento sobre a transpiração dos seres vivos (planta e ser humano). $\mathrm{Na}$ segunda atividade, foi mostrado o globo terrestre para que os alunos respondessem o que as cores representavam. Para organizar os conceitos, na terceira atividade foi construído coletivamente um Mapa Conceitual com as figuras que foram trazidas de casa, utilizando a questão focal: Onde está a água? A aplicação do conhecimento deu-se a partir da retomada da ideia da problematização inicial, de que a água está em praticamente todo lugar. Foi mostrado um cartaz onde aparecia a quantidade de água em alguns seres vivos e, em seguida, discutiu-se com os alunos o processo de transpiração nos seres vivos. Para finalizar, os estudantes realizaram uma pesquisa sobre o rio Iguaçu que foi retomada no encontro seguinte.

Nestas aulas foram desenvolvidos conhecimentos científicos sobre a água, além das interações com a sociedade e ambiente, por meio da percepção da presença e da importância da água para a vida em nosso planeta.

A aulas 3 e 4 abordaram o estudo da poluição e a contaminação da água em Araucária e em outras cidades. O objetivo apresentar e discutir como os impactos da ação humana podem ser prejudiciais à água, trazendo consequências para a saúde. A aula teve início com alguns questionamentos relativos à problematização inicial: Ao ingerir a água proveniente de locais diferentes você percebe alterações no sabor ou todas tem o mesmo gosto? Lembrando da cor da água do Rio Iguaçu você pode afirmar que ela é boa para beber? Como você acha que está a água do Parque em relação ao Rio Iguaçu? Em seguida, foi apresentado um vídeo do Parque que fica ao lado da escola e distribuído um roteiro de observação para ser preenchido. É importante salientar que neste dia estava marcada uma visita neste Parque, porém devido ao mau tempo, a atividade de campo teve que ser cancelada. Os alunos permaneceram em sala e assistiram ao vídeo da visita que foi gravado anteriormente pelos pesquisadores. Logo após, os discentes construíram coletivamente um Mapa Conceitual a partir das observações que foram realizadas após o vídeo, utilizando as seguintes questões focais: Como a água dos rios está sendo utilizada? Como é a cor, a transparência e o cheiro da água? Há seres vivos e agentes poluentes, como lixo, espuma, óleo, esgoto? As questões iniciais foram retomadas e, em seguida, foi realizada uma exposição com fotos atuais do Rio Iguaçu, com discussões sobre a importância da redução na produção de lixo, além de reflexões sobre consumismo e consumo sustentável e os efeitos da mídia para o consumo. Essa retomada carac- 
terizou a etapa da organização do conhecimento. A aplicação do conhecimento se deu por meio da comparação do roteiro de pesquisa sobre as condições do rio Iguaçu (previamente preenchida) e o roteiro de observação do parque, a fim de que os alunos percebessem os impactos da ação humana sobre a água em diferentes localidades.

Nestas aulas foram desenvolvidos conhecimentos científicos e tecnológicos, além das interações com a sociedade e ambiente, com debates sobre os impactos da ação humana sobre a água, tais como a poluição, a contaminação por organismos patogênicos, além de discussões acerca dos benefícios e prejuízos que as tecnologias podem trazer para a sociedade e $o$ ambiente.

Nas aulas 4 e 5 foi dado continuidade aos conteúdos tratados anteriormente, com ênfase para as principais fontes poluidoras em Araucária e outras cidades. O objetivo foi fazer com que os alunos identificassem a poluição e contaminação da água em Araucária e em outras cidades, relacionando essa poluição com seus principais agentes poluidores. A aula iniciou com a etapa de problematização inicial, na qual foi realizado o seguinte questionamento: Quais são os principais poluidores das águas da cidade de Araucária? Os alunos emitiram suas opiniões. Logo após, na etapa de organização do conhecimento, os alunos realizaram a leitura de um texto sobre um acidente ambiental, grifaram os conceitos principais do texto e, coletivamente, fizeram uma síntese em forma de Mapa Conceitual. Ao término desta atividade, foram mostradas algumas imagens de indústrias no Paraná e seus respectivos ramos de atividade para que, após análise coletiva das imagens, discussão e reflexão fossem identificados aspectos positivos e negativos de tais atividades. Em seguida, os estudantes preencheram um quadro de questões sobre os principais agentes poluidores da água, além de inferir sobre as causas, os responsáveis e os impactos desses tipos de poluição. A aplicação do conhecimento se deu a partir da retomada da questão proposta na problematização inicial e após discussão e reflexão, os alunos foram estimulados a listar algumas atitudes e possíveis soluções para se evitar a poluição da água.

Nestas aulas foram desenvolvidos conhecimentos científicos e tecnológicos, além das interações com a sociedade e ambiente, com debates sobre os impactos da ação humana sobre a água, relacionando essa poluição com seus principais agentes poluidores, além disso, foram realizadas discussões acerca dos benefícios e prejuízos desses agentes poluidores. 
As aulas 6 e 7 abordaram as doenças causadas pela falta de higiene e saneamento básico. Estas aulas objetivaram refletir sobre as doenças de veiculação hídrica com contaminação por organismos patogênicos. No início da aula foi explicado sobre as consequências da falta de redes de água tratada e de esgoto para as pessoas e, em seguida, foi questionado: Quais as consequências decorrentes do fato de beber água contaminada? Esta etapa caracterizou a problematização inicial. Para a organização do conhecimento, foi apresentado um vídeo com um documentário sobre a poluição da água. A seguir, foi realizada uma leitura individual e coletiva de um texto que apresentava e discutia a contaminação em garrafas e galões de água mineral. Foi solicitado que os alunos destacassem as partes importantes do texto para a elaboração de um Mapa Conceitual como tarefa de casa. Em seguida, os alunos foram reunidos em grupos e realizaram um trabalho sobre doenças causadas pela falta de higiene e saneamento básico. Após a confecção dos cartazes, os alunos apresentaram as conclusões para os colegas da turma. A aplicação do conhecimento decorreu do questionamento sobre a higienização das garrafinhas de água que as crianças levam para a escola. Em seguida, foi retomada a importância dos cuidados básicos com a ingestão de água, com a higiene pessoal, dos alimentos, além da limpeza adequada dos recipientes.

Nestas aulas foram desenvolvidos conhecimentos científicos e interações com a sociedade e ambiente ao proporcionar discussões sobre questões relacionadas à higiene, doenças veiculadas ou relacionadas com o contato e a ingestão de água contaminada.

As aulas 8 e 9 abordaram as noções de saneamento básico, estação de tratamento de água (ETA), poluição e contaminação da água pelo ser humano. O intuito foi compreender o conceito de saneamento básico e sua importância para a saúde das pessoas. Também objetivou inserir noções sobre tratamento de água, despoluição de rios, coleta, redução de lixo, de modo que os alunos entendessem a importância do saneamento básico para a saúde das pessoas e para o meio ambiente. A problematização inicial ocorreu por meio de uma fala sobre o descaso das pessoas e da sociedade em relação aos cuidados com a água e com a introdução do seguinte questionamento: Como você acha que a água chega até a sua torneira na escola e na sua casa? Para organização do conhecimento foram apresentadas algumas imagens de pessoas em contato com água contaminada. Após a discussão sobre os riscos evidenciados, foi realizada a leitura coletiva de um texto que apresentava a 
deficiente distribuição da rede de esgoto no Brasil e na cidade de Araucária. Em seguida, foi mostrada uma animação com detalhes de como se dá o tratamento da água para que ela chegue limpa às casas, além da realização de uma atividade sobre as instalações hidráulicas de uma casa. A aplicação do conhecimento foi realizada com a confecção de um Mapa Conceitual com a questão focal: Quais são as etapas do saneamento básico, cuidados e utilidade da água para as pessoas? Em seguida, com a mediação da professora, foi feito um mapa coletivo com os mesmos conceitos.

Nestas aulas foram desenvolvidos conhecimentos científicos e tecnológicos e interações com a sociedade e ambiente ao proporcionar discussões sobre as medidas de controle dos impactos da ação humana sobre a água, como os processos de tratamento para tornar a água potável.

As duas últimas aulas abordaram o mesmo assunto, porém tiveram ênfase nas estações de tratamento de esgoto (ETE), tendo como objetivo noções sobre o processo de funcionamento das ETE, relacionando os aspectos envolvidos em seus processos, de modo que os alunos pudessem compreender a importância dos mesmos para o reaproveitamento da água. A problematização inicial se deu com uma retomada de aulas anteriores sobre o Rio Iguaçu, sobre a questão do tratamento da água e o destino das águas servidas, com os seguintes questionamentos: Você sabe de onde vem a água consumida em sua casa? Para onde vai essa água depois de utilizada? Ela pode ser reaproveitada? Como? Para a organização do conhecimento foi realizada a leitura coletiva de dois textos, um sobre a hidrografia de Araucária e outro sobre a procedência da água consumida na cidade. Após leitura individual e coletiva de um texto, foram retomadas as questões da problematização inicial seguidas de uma reflexão sobre hábitos diários em relação ao uso da água e seu desperdício. Em seguida, foi mostrada uma animação com detalhes de como se dá o tratamento de esgoto. A aplicação do conhecimento foi realizada, em duplas, por meio da confecção de um Mapa Conceitual com a questão focal: o que nós aprendemos sobre a água?

Nestas aulas foram desenvolvidos conhecimentos científicos e tecnológicos e interações com a sociedade e ambiente ao proporcionar discussões sobre a origem da água consumida em Araucária, além das medidas de controle dos impactos da ação humana sobre a água, como os processos de tratamento de esgoto, a importância destes para o reaproveitamento da água proveniente de rios e esgotos. A sequência de atividades foi finalizada com a resposta para a questão principal: água: de onde vem, para onde vai? 
Para análise desses dados, foi utilizada a técnica da análise textual discursiva (ATD). As ações descritas neste trabalho foram estruturadas a partir de quatro etapas: I- pré-elaboração da sequência didática; II- programa de formação com a discussão e aprovação da sequência didática; III- validação da sequência didática; e IV aplicação da sequência didática. A constituição dos dados foi realizada a partir da implementação da sequência didática, da observação e análise crítica das aulas, das transcrições das falas dos sujeitos investigados e dos relatórios descritivos das aulas referentes à intervenção de uma das professoras participantes da pesquisa. O processo de análise foi composto por duas etapas: caracterização das categorias a priori e análise e discussão dos resultados.

De acordo com Moraes e Galiazzi (2011), a ATD pode ser definida com uma ferramenta analítica ou procedimento de pesquisa que estabelece o caminho para um processo investigativo. É considerada uma metodologia aberta que consiste num trabalho intenso de leitura e escrita do pesquisador, o que requer envolvimento e impregnação nos fenômenos investigados para que novas compreensões possam emergir. Concretiza-se a partir de um conjunto de documentos que são os dados, denominado de corpus da pesquisa, constituído essencialmente de produções textuais.

O ciclo de análise é formado por três fases principais: unitarização, categorização e emergência. A fase da unitarização é composta por dois movimentos principais: movimento desconstrutivo e processo reconstrutivo. $\mathrm{O}$ movimento descontrutivo se refere a um processo de desmontagem de textos, de caos, de desorganização, de fragmentação, de identificação e expressão de unidades elementares obtidas a partir do material do corpus da pesquisa. No processo seguinte, há a reconstrução rigorosa das compreensões do pesquisador, sempre a partir do mergulho em significados coletivos expressos pelos sujeitos da pesquisa. Somente a partir da unitarização é que são criadas as condições para a categorização.

$\mathrm{Na}$ fase da categorização, as categorias começam a emergir, inicialmente imprecisas e inseguras, mas, gradativamente, vão sendo explicitadas com rigor e clareza. Este processo exige uma organização de informações que são comuns, podendo ocorrer mediante comparação constante entre unidades que foram definidas no momento inicial da análise, levando ao agrupamento de elementos semelhantes (MORAES; GALIAZZI, 2011).

É importante destacar que neste estudo a formulação das categorias foi definida $a$ priori. As categorias surgiram naturalmente, a partir do próprio problema levantado durante a investigação. Portanto, os elementos descritos no levantamento do pro- 
blema, tais como: conhecimentos, valores, atitudes e habilidades necessárias para o exercício da cidadania constituíram-se previamente em categorias de análise.

A análise destas categorias foi realizada por meio da apresentação das unidades de análises provenientes das falas dos alunos e da professora, bem como do registro de algumas atividades realizadas durante a aplicação da sequência didática.

\section{Resultados e discussão}

Ao longo dos primeiros anos de escolaridade, os alunos ampliam seu repertório e desenvolvem conhecimentos práticos e contextualizados, essenciais às necessidades que se apresentam no contexto de vida da sociedade atual e, em conjunto com o desenvolvimento de conhecimentos abstratos, compõem uma visão geral de mundo. Para demonstrar como isso ocorre, inicialmente serão apresentadas as categorias a priori: desenvolvimento de conhecimentos, valores, atitudes e habilidades evidenciadas durante a implementação da sequência didática. A Tabela 1 apresenta as categorias analisadas e como elas se configuram em relação à construção do conhecimento discente.

Tabela 1: Categorias a priori com os respectivos números de unidades de análise referentes ao desenvolvimento de conhecimentos, valores, atitudes e habilidades

\begin{tabular}{c|c|c|c|c|c}
\hline Categoria & Conhecimentos & Valores & Atitudes & Habilidades & Total \\
\hline $\mathrm{N}^{\circ}$ de Ocorrência & 66 & 40 & 19 & 11 & 136 \\
\hline
\end{tabular}

Fonte: Dados da Pesquisa

Os resultados indicaram o predomínio do desenvolvimento do conhecimento científico na maioria dos relatos. Já a categoria dos valores foi intermediária. Quanto à categoria das atitudes, foram localizadas 19 ocorrências. Devido ao seu caráter mais prático, a categoria desenvolvimento de habilidades foi localizada, em sua maioria, no registro das atividades.

\section{a) Desenvolvimento de conhecimentos Científicos}

Na categoria representada pelo desenvolvimento de conhecimentos científicos, foram identificadas 66 ocorrências presentes nos relatos dos alunos e no registro das atividades. Portanto, o conhecimento científico foi a categoria mais 
evidenciada nos relatos e discussões. Isto ocorreu justamente porque do ponto de vista da escola, o conhecimento é o elemento de maior relevância.

Partimos do pressuposto de que a Ciência é um conhecimento que colabora para a compreensão do mundo e suas transformações, e para o reconhecimento do homem como parte do universo e como indivíduo. Neste sentido, o conhecimento científico pode ser definido como um conjunto de atividades humanas, de caráter histórico e, portanto, não neutras (BRASIL, 1997b). A obtenção do conhecimento científico ocorre gradualmente, proporcionando a aquisição do conceito científico. Este processo se dá ao longo do Ensino Fundamental, com início nos primeiros ciclos de escolaridade e se configura nos anos finais. No entanto, nos anos intermediários do ensino fundamental, os alunos já possuem um repertório de imagens e ideias mais elaboradas, sendo capazes de receber uma variedade de informações abrangentes sobre a temática abordada (BRASIL, 1997b).

Inicialmente, é possível verificar que os alunos construíram o conhecimento sobre a presença da água no planeta ao relatarem que a água se encontrava no ser humano, nos animais, nas plantas, frutas e verduras, ao afirmar que: 'tem água no ser humano, nas plantas, verduras' (E2A18), 'tem água nas frutas' (E2A13) e 'tem água nas pessoas, nos animais, nas plantas e nas frutas'(E2A6).

As falas demonstram um progresso em relação aos conhecimentos prévios, quando a maioria dos estudantes só identificava a presença de água quando ela era aparente, como no caso da maioria das figuras trazidas que continha rios, lagos e mares, conforme consta na Figura 1.

Figura 1: Onde podemos encontrar água?
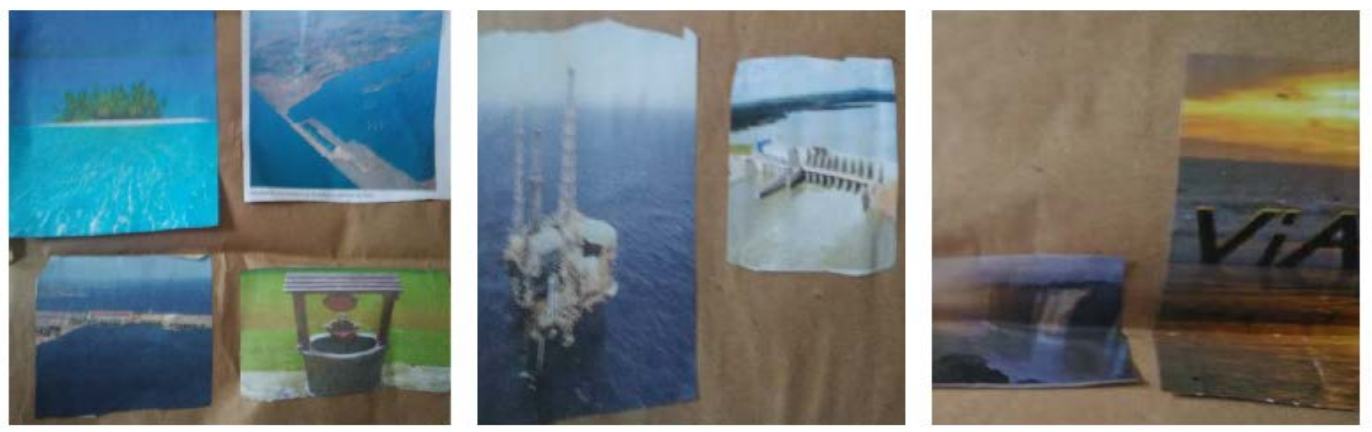

Fonte: Dados da Pesquisa. 
É importante ressaltar que, além do debate em sala de aula e da exposição das imagens trazidas de casa pelos estudantes, foram desenvolvidas outras atividades, tais como um experimento sobre a transpiração dos seres humanos e das plantas, além da exposição de um cartaz com a porcentagem de água presente nos grupos abordados para que os alunos pudessem observar a existência de água em outras fontes.

As atividades investigativas sobre as relações entre a água e os seres vivos podem propiciar o entendimento da dinâmica ambiental. Ao estudar estas relações, os alunos se aproximam de diferentes conhecimentos científicos relacionados ao tema água:

Problemas relevantes — onde existe água no planeta? A água das nuvens, dos seres vivos e dos rios é a mesma? A água na natureza nunca acaba? - permitem discutir a presença da água no planeta e suas transformações. Essas questões, entre outras, se constituem em convites para os alunos expressarem suas suposições, buscarem informações e verificá-las. Possibilita ao professor conhecer as representações dos alunos e organizar os passos seguintes de sua intervenção (BRASIL, 1997b, p. 59).

De acordo com Victorino (2007), é de suma importância que o professor discuta com seus alunos que tudo em nosso planeta é regido pela presença desse líquido vital, pois mesmo o ar que se respira vem, em sua maior parte, das microscópicas algas que habitam essa enorme massa formada pelos rios, lagos e oceanos. Sem se convencer que ninguém é capaz de sobreviver um único dia sem água, dificilmente haverá mudanças nas atitudes e comportamentos das pessoas, por isto, P1 na última aula da sequência didática, destaca a importância da água e as consequências do mau uso deste recurso:

A gente às vezes pensa que a água é tão fácil que a gente nem se pergunta de onde ela vem, como ela vem, como ela vai, se ela vai acabar. A gente ouve falar, mas parece muito distante porque ela cai muito fácil para a gente (E6P1).

Sendo assim, a ameaça da falta de água, em níveis que podem até mesmo inviabilizar a nossa existência, pode parecer exagero, mas não é. As consequências do rápido crescimento da população mundial e da concentração dessa população em megalópoles implicam diretamente na qualidade e na quantidade de água disponíveis e já podem ser visíveis em várias partes do mundo (BRASIL, 2005).

De acordo com Czapski (2008), é preciso falar em pouca água, principalmente porque $97,5 \%$ deste líquido precioso só é encontrado nos mares e oceanos, ou seja, 
é água salgada que, em média, contém $35 \mathrm{~g}$ de sal por litro de líquido, sete vezes mais do que o organismo humano aceita. Dos 2,5\% de água que resta, grande parte está congelada nas calotas polares e geleiras, o que dificulta o acesso. Deste modo, é importante investigar de onde vem a água e seus modos de captação na região onde a escola se encontra. É importante pesquisar se a água provém de fontes, de poços, de rios ou riachos, de represas, constando como são e onde se localizam tais fontes (BRASIL, 1997b).

A água que chega até nós, ou que é utilizada de alguma forma, também retorna para a natureza. Captada de um córrego, rio, lago ou reservatório e levada até uma ETA-Estação de Tratamento de Água para se tornar potável, fica armazenada em reservatórios, de onde será distribuída por meio das redes adutoras para as nossas torneiras (VIEIRA, 2006, p. 13).

Após o estudo da origem e destino da água consumida em Araucária, foi necessário conhecer mais sobre as condições ambientais das fontes de água da cidade. Para tanto, na aula E2 foi realizada uma atividade investigativa, que proporcionou aos alunos a realização de uma comparação entre a situação da fonte de água situada ao lado da escola e as condições ambientais do principal e maior rio da cidade: o Iguaçu.

Tem muitos peixes mortos, mas perto da minha casa, eu vi pessoas pescando nesse rio. Também vi uma parte da água marrom e a outra preta, bem escura (E2A8).

O rio está sujo e cheio de lama, mas tinha peixes (E2A18).

O rio está com um cheiro muito ruim, de coisa morta (E2A4).

Deve ter esgoto na água porque ela está muito suja (E2A18).

O Parque Cachoeira está limpo porque funcionários o mantêm assim, no entanto, o Rio Iguaçu está cheio de lixo (E2P1).

Destaca-se que as falas acima se referem a observações das imagens do rio poluído em diversos pontos da cidade. Estas análises foram realizadas pelos alunos, além do suporte de uma visita feita com a turma ao Rio Iguaçu, no início do ano, anteriormente às aulas da sequência didática.

Vieira (2006) ressalta que os rios são muito mais que locais que contém água, já que, neles encontramos uma rica biodiversidade de fauna e flora que oferecem múltiplos benefícios. Infelizmente, o crescimento desordenado das cidades tem maltratado os cursos de água, com desmatamentos, atividades extrativistas, queimadas, agrotóxicos, construções de estradas, moradias irregulares, dentre outros. Com 
estas ações, muitos rios foram modificados e, em muitos casos, não é possível mais reconhecê-los em sua forma e qualidade originais. Ressalta-se que esta atividade buscou desenvolver nos alunos um senso de responsabilidade para os problemas ambientais, além de trazer um significado maior para tais discussões. Os alunos foram estimulados a realizar uma observação crítica do entorno da escola, com ênfase para a situação das fontes de água da região.

Essa proposta não trata de uma compreensão qualquer, mas de uma forma de construção de conhecimento que associa os conteúdos conceituais às ações cotidianas.

Os conceitos podem ser mais significativos se os alunos puderem fazer, individual ou coletivamente, observações da dinâmica do ambiente local. O debate e a análise dessas observações serão mais ricos com sua sistematização de forma coletiva. Nessa condição, é possível discutir tanto a dinâmica, em si, quanto as diferentes leituras individuais desses fatos-eventos (BRASIL, 1998, p. 210).

Para Carvalho et al. (1998), propostas de ensino que utilizam a investigação e a experimentação, desenvolvem a autonomia do aluno, já que ele deixa de ser um simples observador de aulas expositivas para ter um papel ativo nas aulas, por meio dos questionamentos e inferências que realize e que o auxiliam na construção do seu conhecimento.

Nesse sentido, a sequência didática com abordagem CTSA demonstra o papel da educação ambiental crítica quando introduz nas aulas investigações que giram em torno de temas locais e que sejam do interesse dos alunos, os quais inserem motivação para que os mesmos se envolvam com as discussões em sala de aula e desta forma, trabalhem de maneira que os assuntos englobem não só as ciências naturais, mas também a sociedade, as tecnologias e o ambiente, percebendo e argumentando sobre o modo como estes elementos se relacionam (SASSERON; CARVALHO, 2007).

Posto isso, elencamos relatos dos alunos em que foram identificadas tais relações:

Quando as pessoas entram em contato com a água suja podem pegar infecção ou doenças (E2A6).

A gente tem que cuidar com a água mineral porque às vezes a gente fica preocupado só com a água da torneira porque às vezes a contaminação não está na água, mas nas embalagens como galões e garrafinhas (E4A6).

Nós aprendemos sobre as bactérias, prevenção, sintomas e como combater as bactérias da água (E4A18). 
As unidades de análise provenientes das falas acima demonstram o estabelecimento de relações e conhecimentos entre o consumo de água contaminada e as condições de higiene inadequadas com os problemas mais graves de saúde. Desta forma, os relatos apresentam dados que fomentam a compreensão das relações CTSA, uma vez que os alunos informaram as consequências da poluição e contaminação da água para a saúde das pessoas. Posteriormente, os estudantes realizaram análise de imagens e leitura de textos que estavam presentes nas atividades da sequência didática.

Após essa etapa, foi necessário que os alunos identifiquem os processos de captação, distribuição e armazenamento de água associando-os com as condições necessárias à preservação da saúde. Essa relação foi localizada na unidade de análise abaixo:

A Sanepar deve extrair a água dos rios com um cano grande, daí devem tratar a água e depois do tratamento ela vai limpando a água, daí ela distribui toda a água para as casas (E5A18).

O sentido identificado demonstra a importância das medidas sanitárias sobre a água:

Como esse assunto é bastante amplo e complexo e pode ser abordado nos seus diferentes aspectos (científico, social, político, comportamental), sugere-se priorizar: noções sobre captação da água, tratamento e distribuição para o consumo; os hábitos de utilização em casa e na escola adequados às condições locais; a necessidade e as formas de tratamento dos detritos humanos; coleta, destinação e tratamento de esgoto com procedimentos possíveis adequados às condições locais (esgotamento sanitário, fossas e outros); as práticas que evitam desperdícios no uso cotidiano de recursos com a água, energia e alimentos; a minimização da contaminação das águas na agricultura pelo uso de métodos mais eficientes de irrigação e os cuidados com a utilização de insumos e escoamento dos restos produzidos com a criação de animais (BRASIL, 1998, p. 223).

O relato acima demonstra a promoção das relações CTSA, já que o mesmo permite o contato com temas relacionados ao saneamento básico, além de consequências das atividades humanas sobre a água. Além de saber que o acesso à água e às condições mínimas de saneamento básico são um direito de todos, os alunos foram alertados da necessidade de colaborar na conservação dos recursos naturais. No entanto, mesmo com todas as medidas de controle de impactos da ação humana sobre a água, grandes acidentes ambientais continuam ocorrendo. Portanto, para desenvolver um posicionamento crítico diante desses acontecimentos, se faz necessário discutir os desdobramentos dos fatos. 
Foi com esse intuito que, na aula E3, foram desenvolvidas atividades de leitura e discussão de uma reportagem sobre o vazamento de óleo cru da Petrobras no ano de 2000 que afetou os rios Barigui e Iguaçu, em Araucária. Os alunos comentaram o texto, argumentando sobre o ocorrido: 'O óleo asfixiou algumas aves. As aves que beberam a água do rio podem ter sofrido as consequências, não somente os peixes' (E3A6); 'Eu acho que contaminou os peixes' (E3A24) e 'A poluição também mata os animais' (E2A13).

Os sentidos identificados nas unidades de análises acima demonstram um paralelo em relação às condições ambientais do principal e maior rio da cidade: o rio Iguaçu. Os estudantes puderam perceber, por meio da discussão sobre o acidente ambiental, que a degradação do meio ambiente é um dos aspectos mais críticos da poluição causada pelo homem. Rios que apresentavam água em quantidade e qualidade, hoje estão seriamente ameaçados.

A atividade desenvolvida sobre $o$ acidente ambiental e que foi baseada nos pressupostos da abordagem CTSA proporcionou aos alunos uma discussão e, consequentemente, uma postura crítica diante dos fatos que foram abordados, evidenciando que:

\begin{abstract}
Se não ensinarmos as ciências a partir de uma perspectiva plural, como práticas sociais com dimensões filosóficas, históricas e culturais, em um espaço escolar compromissado com ideais e valores que superam interesses utilitários e produtivistas, formaremos cidadãos oficialmente alfabetizados, formalmente escolarizados, mas sem intimidade com o conhecimento científico, sem real apreço pela pesquisa científica como uma forma de vida, que não cultivam a ciência como parte fundamental da vida cultural. É preciso cultivar o diálogo e o exercício crítico do debate no espaço escolar. É por meio do diálogo que realmente efetivamos uma coletividade, que um somatório de indivíduos no mesmo espaço pode ser tornar uma comunidade (SILVA; VIDEIRA, 2020, p. 1063).
\end{abstract}

Sasseron e Carvalho (2008) acreditam que temas que são de interesse dos alunos funcionam como um fator motivacional para a participação efetiva nas discussões em sala de aula. Sendo assim, o trabalho pedagógico nessa perspectiva engloba não somente conceitos relativos às Ciências Naturais, como também discussões mais amplas relacionadas à sociedade, às tecnologias e ao meio ambiente e suas inter-relações.

Por meio da reflexão e do diálogo também é possível resgatar as características do ambiente onde ocorreram vários fatos e de que maneira os personagens se relacionavam com elas ou, ainda, quais as transformações ambientais, ocorridas após 
esses fatos, e quais ambientes se observam hoje no lugar onde se vive. O posicionamento crítico diante de alterações no ambiente depende também da possibilidade de previsão dos seus desdobramentos (BRASIL, 1998).

Ainda na aula E3, foi solicitado aos alunos que conversassem com seus familiares sobre a notícia mostrada na aula para verificar se lembravam do fato e como repercutiu na cidade àquela época.

Figura 2: Atividade acidente ambiental
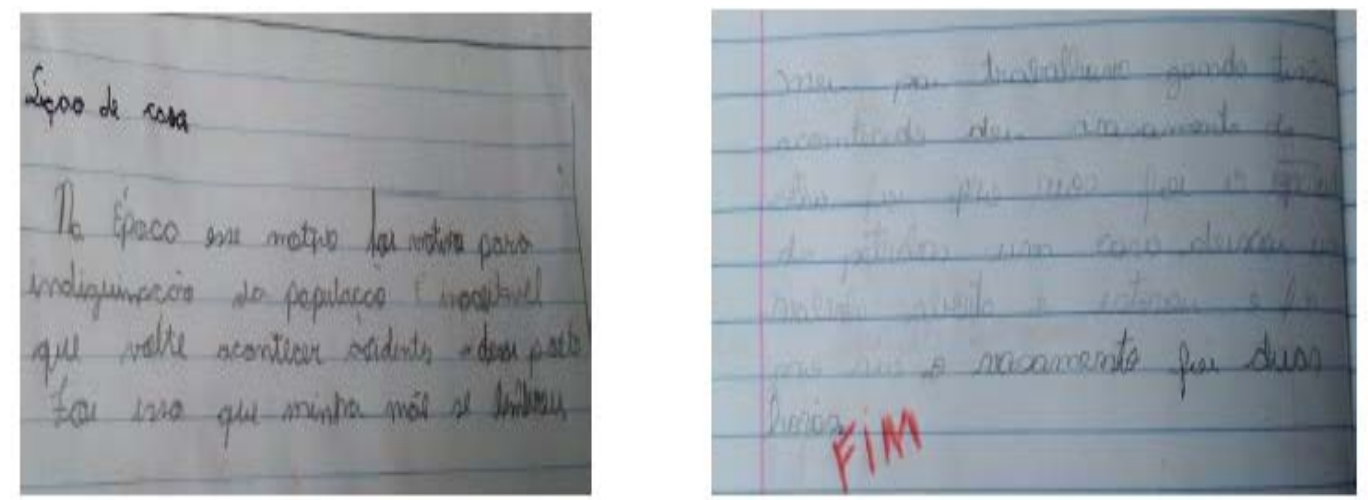

Fonte: Dados da Pesquisa.

Constatamos que os alunos se sensibilizam e reconhecem as mudanças do ambiente local, com maior facilidade, quando são estimulados para reconhecer seus vínculos com o ambiente.

[...] O rádio, a TV e a imprensa constituem uma fonte de informações sobre o Meio Ambiente para a maioria das pessoas, sendo, portanto, inegável sua importância no desencadeamento dos debates que podem gerar transformações e soluções efetivas dos problemas locais. No entanto, muitas vezes, as questões ambientais são abordadas de forma superficial ou equivocadas pelos diferentes meios de comunicação. Notícias de TV e de rádio, de jornais e revistas, programas especiais tratando de questões relacionadas ao meio ambiente têm sido cada vez mais frequentes. Paralelamente, existe o discurso veiculado pelos mesmos meios de comunicação quando propõem uma ideia de desenvolvimento que não raro entra em conflito com a ideia de respeito ao meio ambiente. São propostos e estimulados por meio do incentivo ao consumismo, desperdício, violência, egoísmo, desrespeito, preconceito, irresponsabilidade e tantas outras atitudes questionáveis dentro de uma perspectiva de melhoria de qualidade de vida. Por isso, é imprescindível os educadores relativizarem essas mensagens, ao mostrar que elas traduzem um posicionamento diante da realidade e que é possível haver outros (BRASIL, 1998, p. 187). 
De acordo com Santos (2007), com o avanço tecnológico e industrial nos últimos anos, houve um significativo aumento dos problemas ambientais. É nesse cenário que surge a abordagem de ensino CTSA, com a discussão de temáticas que proporcionem a reflexão sobre as consequências ambientais do desenvolvimento científico e tecnológico. Nessa perspectiva, o principal objetivo de um currículo CTSA é desenvolver a capacidade de tomada de decisão e enfatizar questões ambientais com o objetivo de promover a educação ambiental.

Sendo assim, as investigações realizadas na aula sobre a origem dos diferentes poluentes com os prováveis prejuízos aos seres vivos compõem uma discussão básica sobre termos como sujeira, poluição, poluentes e lixo. Problemas ligados ao uso e à poluição das águas doces e oceânicas, envolvendo a extração de petróleo e os desastres ambientais também devem ser abordados.

No que se refere às noções de saneamento básico, o assunto da distribuição de água por meio de redes de abastecimento pode ser trabalhado a partir de maquetes ou imagens que representem todo o processo, desde a captação até a chegada da água às casas. Para esta atividade é importante que o professor oriente os alunos sobre o conjunto de estruturas que permite o transporte da água (canos). Imagens que mostrem as ligações entre caixas de água e encanamentos de edifício ou de casa facilitam a compreensão sobre a relação direta entre a pressão da água e a altura do recipiente de estoque (BRASIL, 1997b).

Para demonstrar como os conhecimentos sobre distribuição e armazenamento domésticos de água foram desenvolvidos na sequência didática, são apresentadas algumas atividades da aula 5 elaboradas a partir do desenho das instalações hidráulicas de uma casa, o qual possibilitou a visualização de todo processo que a água passa até chegar as casas. 
Figura 3: Análise do desenho das instalações hidráulicas de uma casa
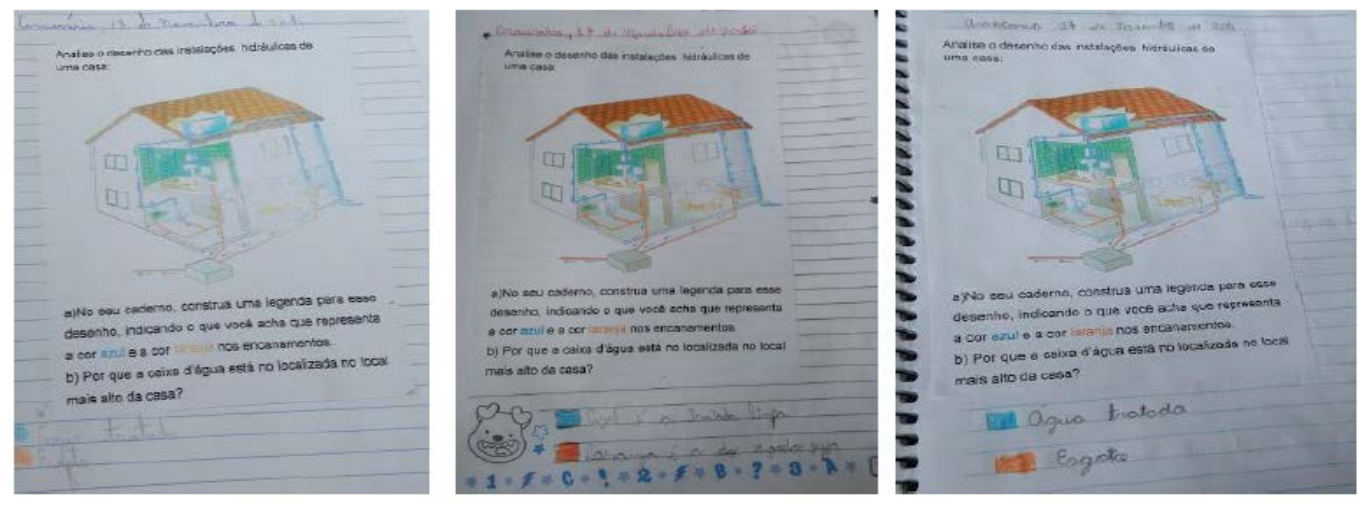

Fonte: Dados da Pesquisa

Como demonstrado, a atividade consistiu na realização de uma legenda para as instalações hidráulicas de uma residência, conforme mostradas no desenho de uma casa. Além disso, foram realizados questionamentos sobre o fato da caixa d'água estar localizada no lugar mais alto da casa: "Por que a caixa d'água está localizada no local mais alto da casa?" (E5P1). "É por causa dos canos" (E5A8). "Mas não poderia fazer esses canos mais baixos?" (E5P1). "Por que a caixa tem que ser no local mais alto da casa?" (E5P1). "Para a água escorrer nos canos para ser distribuída" (E5A13).

Após relatos dos alunos, P1 explica como é o processo pelo qual a água passa até chegar às nossas casas:

Quando a água chega da rua, vem com bastante pressão. Vocês já viram quando está chegando água? A gente abre a torneira e sai forte a água, né? A gente escuta até aqueles barulhos quando vai encher a caixa d'água da gente, né? Pensem, quando estamos sem água em casa e a gente abre a torneira e começa a fazer aquela barulheira. Aágua chega com pressão e daí vai para a caixa da água, então ela precisa mesmo estar num lugar mais alto para poder distribuir essa água depois (E5P1).

De acordo com Sasseron (2009), é somente com o auxílio do professor que se torna possível a construção de explicações mais detalhadas e precisas sobre os problemas apresentados. Nesse sentido, o papel do docente é essencial para orientar as discussões, visto que por meio de suas problematizações, os alunos conseguem organizar as informações já existentes e a partir daí, construir explicações para determinado fenômeno ou dúvida. 
Nesse sentido, é função da escola estimular a revisão dos conhecimentos, valorizando-os sempre e buscando enriquecê-los com informações científicas. O conhecimento científico permite apontar para as relações recíprocas entre sociedade e ambiente, marcadas pelas necessidades humanas, seus conhecimentos e valores. As questões sobre a tecnologia, em seus aspectos técnico, organizacional e cultural estão intimamente relacionadas às transformações ambientais, e também são importantes conhecimentos a serem desenvolvidos (BRASIL, 1997b).

\section{b) Desenvolvimento de Valores}

$\mathrm{Na}$ categoria referente ao desenvolvimento de valores foram identificadas 40 ocorrências nos relatos dos alunos e no registro de algumas atividades. No entanto, somente os valores presentes nas falas dos discentes foram selecionados para análise.

Educar em valores é formar moralmente, já que os valores ditam os princípios e as regras que conduzem o comportamento dos seres humanos, que levam as pessoas a estabelecer uma hierarquia sobre as coisas, a concluir que algo é ou não importante, é ou não correto (CARRERAS et al., 2006).

Segundo Gaudiano e Katra (2009, p. 56), "educar em valores, eticamente, significa promover nos sujeitos a elaboração e o desenvolvimento de uma racionalidade moral substantiva, de modo autônomo e comprometido, para que tomem decisões pessoais, através do exercício de sua liberdade responsável”. Por isso, valores como respeito, responsabilidade, criatividade, justiça, solidariedade, crítica, equidade, poderiam constituir um referencial básico para uma exigência ética para os sistemas político-educativos.

De acordo com Santos e Mortimer (2002), os valores de solidariedade, fraternidade, consciência do compromisso social, reciprocidade, respeito ao próximo e generosidade são vistos como o objetivo central da educação CTS. Portanto, a escola precisa ser o lugar onde os valores são pensados, refletidos, e não meramente impostos por fruto do hábito. O espaço escolar deve ser o lugar onde os alunos possam dialogar e entender diferentes pontos de vista (BRASIL, 1997a).

Com base no exposto foi possível observar um senso de responsabilidade do estudante para os problemas ambientais. No caso em questão, o aluno fez referência aos esgotos que são jogados nos rios, pela maioria das pessoas: 'Os principais poluidores são as pessoas, os moradores de Araucária’ (E3A13). 
Para Carreras et al. (2006), a responsabilidade é a capacidade de uma pessoa executar um trabalho sem nenhuma pressão externa, ou seja, esse valor possui uma vertente individual, que leva ao reconhecimento e responsabilização por atos e obrigações das pessoas, bem como pelas suas consequências. Nesse sentido, E3A13 enfatizou sua fala: 'O governo também é responsável' (E3A13). Assim, é importante reconhecer as instâncias do poder público como responsáveis pelo gerenciamento das questões ambientais. Além disso, é necessário conhecer os direitos e deveres do cidadão e saber a quem e como recorrer em caso de denúncias de danos ambientais. Isto contribui para tornar o aluno sujeito participante da sociedade (BRASIL, 1998).

A educação ambiental tem como premissa contribuir para uma visão humanista, uma postura ética e para o exercício da cidadania, com base no empoderamento individual e coletivo que, por sua vez, resulta de processos de formação que incitam um posicionamento crítico e a construção compartilhada de um conhecimento transformador da realidade socioambiental. Uma educação ambiental com viés CTSA incorpora as preocupações políticas às socioambientais, uma vez que preferimos uma 'primavera dialógica', com clara ênfase à valorização das interações, baseada na liberdade de expressão das manifestações populares e na responsabilidade dos poderes públicos, com igualdade de direitos e diversidade de visões. Esta abordagem está comprometida com a compreensão das múltiplas relações CTSA e com o empoderamento das populações para o enfrentamento das situações de vida - a partir de sua percepção, valores e interpretação dos problemas locais, regionais, nacionais e planetários (GRYNSZPAN, 2014, p. 11).

Nesse sentido, ao discutir problemáticas ambientais, "não se pode esquecer que a escola não é o único agente educativo e que os padrões de comportamento da família e as informações veiculadas pela mídia exercem especial influência sobre os adolescentes e jovens” (BRASIL, 1998, p. 187). Sendo assim, as unidades de análise destacadas a seguir fazem referência à influência da mídia nos consumidores: “ $A$ televisão mostra propaganda de boneca” (E2A24); "As promoções das lojas que passam na TV" (E2A18); "Sim, porque mostra coisas que os personagens têm" (E2A18).

A crítica, como instrumento de análise da realidade, auxilia os alunos a construírem seus próprios critérios, permitindo-lhes tomar decisões apropriadas (CARRERAS et al., 2006). Por isso, quando os alunos A24 e A18 percebem que a televisão serve também para mostrar propagandas, promoções e personagens estão estabelecendo noções sobre as relações de consumo, o que proporciona uma discussão dos valores envolvidos nessas decisões.

Scotto, Carvalho e Guimarães (2007) ressaltam que discussões sobre consumo, que estejam relacionadas somente com a característica manipuladora da mídia 
mediante as atitudes passivas dos sujeitos, podem acabar desprezando as demandas sociais que as próprias pessoas fazem à televisão. Por isso, é importante tentar entender o consumo não mais a partir de explicações que considerem somente a visão econômica de produção, mas como um processo cultural de múltiplas facetas.

Nesse sentido, considerar o consumo em uma só dimensão (enxergá-lo como um mal ou ato a ser controlado) torna-se um ato, no mínimo, simplista. Em vez de tentar uma redução geral dos padrões de consumo, é importante cogitar a existência de um patamar mais equitativo dos usos dos recursos ambientais, pois as situações de desigualdade social revelam que muitas pessoas deveriam ter o direito legítimo de consumir, enquanto outros precisariam reduzir drasticamente seus índices de consumo. (SCOTTO; CARVALHO; GUIMARÃES, 2007).

Outro ponto a ser considerado é a valorização da vida e dos recursos naturais:

A gente pode morrer porque que se a gente contaminar toda a água vai morrer de sede ou de alguma doença (E4A18).

Para funcionar o nosso corpo, porque sem água a gente não vive (E2A6).

A poluição das fábricas pode acabar com a água (E2A18).

Essas relações foram identificadas nas unidades de análise acima, quando os alunos demonstram que reconhecem o valor e a importância que a água possui para a vida dos seres humanos e os impactos da ação humana sobre este recurso. Todas as pessoas são capazes de reconhecer que a água é um elemento essencial à vida. No entanto, nem todos se preocupam com ela. Geralmente, o valor da água é apenas econômico, sem preocupação com as questões sociais. Para desenvolver uma ideia integrada sobre a água, é importante entender que ela é parte do ecossistema e constitui um bem social e econômico, na qual a quantidade e qualidade devem determinar seu uso (VICTORINO, 2007).

\section{c) Desenvolvimento de Atitudes}

Na categoria desenvolvimento de atitudes, foram localizadas 19 unidades de análises. As atitudes no ensino de Ciências Naturais estão relacionadas com o desenvolvimento de posturas na relação entre o homem, o conhecimento e o ambiente (BRASIL, 1997b). 
Tais posturas devem possuir um valor pessoal e podem ser definidas quando se atribui sentimentos e valores a determinados fatos, normas, regras e comportamentos que resultam numa atitude consciente. Exemplos dessas atitudes poderiam ser revelados na maneira de ver e entender a ciência, adotando estereótipos aos profissionais que fazem ciência, ou até mesmo certos posicionamentos diante de conquistas científicas e tecnológicas e as teorias científicas (NIGRO, 2015).

\begin{abstract}
Os fundamentos científicos devem subsidiar a formação de atitudes dos alunos. Não basta ensinar, por exemplo, que não se deve jogar lixo nas ruas ou que é necessário não desperdiçar materiais, como água, papel ou plástico. Para que essas atitudes e valores se justifiquem, para não serem dogmas vazios de significados, é necessário informar sobre as implicações ambientais dessas ações. Nas cidades, lixo nas ruas pode significar bueiros entupidos e água de chuva sem escoamento, favorecendo as enchentes e a propagação de moscas, ratos ou outros veículos de doenças. Por sua vez, o desperdício de materiais, considerado no enfoque das relações entre os componentes do ambiente, pode significar a intensificação de extração de recursos naturais, como petróleo e vegetais que são matéria-prima para a produção de plásticos e papel (BRASIL, 1997b, p. 37).
\end{abstract}

A necessidade de separar e reciclar o lixo foram ações que sobressaíram nos fragmentos destacados a seguir, mas, por si só, não são a única e melhor solução para o problema do lixo: "Tem que reciclar os lixos" (E3A6); "Separando os lixos" (E3A6).

Vieira (2006) explica que ainda hoje a maioria das pessoas acredita que pode produzir lixo sem nenhuma restrição, porque a reciclagem é uma solução fácil para problema. Realmente, reciclar pode ser um método eficiente, principalmente para aqueles materiais que não podem ser reutilizados, mas para resolver a questão do lixo, outros processos devem ser associados, num sistema de passos e etapas a serem desenvolvidas em conjunto.

As unidades de análise destacadas abaixo demonstraram uma preocupação com o descarte e destino correto do lixo. Observam-se nos depoimentos outras atitudes que podem ser tomadas a respeito dessa questão: "parar de jogar lixo na rua" (E3A24); "Tem que limpar a água. Tem que tirar o lixo da água, senão ele vai para o rio e contamina a água" (E5A13); "Não jogar esgotos no rio" (E3A5).

Ainda de acordo com Vieira (2006), a preocupação com o descarte e destino correto do lixo deve existir, já que dificilmente ele terá um direcionamento adequado se for jogado em outro lugar que não seja a lixeira. Contudo, sabendo que enquanto houver gente no planeta sempre haverá descarte de lixo, outra solução viável é tentar reduzir a sua quantidade. Desta forma, campanhas e atividades 
de educação ambiental devem ser realizadas para fazer com que todas as pessoas adotem um consumo sustentável, pois reduzir a produção do lixo é tarefa pessoal dos consumidores, do poder público e dos fabricantes.

$\mathrm{Na}$ escola, podem-se criar formas adequadas de coleta e destino do lixo, reciclagem e reaproveitamento de materiais. É possível também discutir comportamentos responsáveis de 'produção' e 'acondicionamento' em casa, e nos espaços de uso comum; o tipo de embalagens utilizado nos produtos industrializados e as diversas formas de desperdício; o prejuízo causado por produtos descartáveis não biodegradáveis; formas de pressionar os produtores para mudanças no sistema de produção e materiais empregado. Deve-se, também, propiciar contato com estratégias de destinação utilizadas por outras localidades, numa perspectiva de busca de soluções (BRASIL, 1998, p. 224).

Em contrapartida, propostas de ações centradas na reciclagem, reaproveitamento, redução e desperdício de recursos quando desvinculadas da problematização das causas do acúmulo desses materiais e, principalmente, de outras relações sociais que comandam a lógica desenvolvimentista, sugerem um senso comum e não colaboram para a compreensão da realidade multidimensional que os alunos estão inseridos (BRASIL, 1998; ZAIONS, 2017).

Por intermédio da apreciação de exemplos é possível verificar as dimensões dos conteúdos implicados a um determinado problema. Investigações sobre diferentes fontes poluidoras da água, sobre os limites dos usos de recursos hídricos e suas implicações ambientais, bem como o acesso das populações a esse bem ampliam e contextualizam o tema. Neste sentido, as unidades de análise destacadas abaixo, demonstram que, tanto os alunos como suas famílias já adotam atitudes que sugerem um uso racional da água:

É, agora eu uso a água da chuva. Minha mãe pega o balde e coloca lá na água da chuva e depois lava a calçada com aquele mesmo balde (E6A18).

Minha mãe pega a água da máquina para lavar a calçada (E6A13).

Às vezes minha mãe deixa o carro para fora para chuva lavar (E6A4).

É melhor economizar, cuidar da água e não jogar lixo (E4A18).

Podemos ajudar economizando energia (E2A24).

Podemos ajudar com economia na água da piscina, sem encher e esvaziar várias vezes (E2A18).

Não gastar muita água e luz (E3A19). 
Mesmo que as falas acima demonstrem ações ainda incipientes em relação à economia e aos usos da água em nosso país, as mesmas já começaram a ser desenvolvidas. Assim, defende-se que:

Um trabalho educativo pode contribuir para incorporar novas técnicas aos comportamentos culturalmente cristalizados e trazer mudanças significativas na utilização dos recursos. Tais alternativas podem ser muito criativas, pouco dispendiosas e, na escola, algumas delas podem ser discutidas e implementadas, como as formas de evitar o desperdício de água e energia elétrica etc. (BRASIL, 1998, p. 222).

Os cuidados com a higiene são uma condição para uma vida saudável. É preciso valorizar atitudes e comportamentos favoráveis à saúde, em relação à alimentação e à higiene pessoal, desenvolvendo a responsabilidade no cuidado com o próprio corpo e com os espaços que habita (BRASIL, 1997b).

Diante disso, as atividades elaboradas na aula E4 incluíram o desenvolvimento de atitudes para evitar as doenças causadas pelo contato e ingestão de água contaminada: "Tem que passar álcool 70 'na boca das coisas' onde vai colocar a água” (E5A18); "Eu só beberia a água do parque se a Sanepar limpasse" (E2A11).

Os fragmentos destacados acima demonstram a importância da reflexão sobre as consequências da falta de higiene:

A promoção da saúde ocorre, portanto, quando são asseguradas as condições para a vida digna dos cidadãos, e, especificamente, por meio da educação, da adoção de estilos de vida saudáveis, do desenvolvimento de aptidões e capacidades individuais, da produção de um ambiente saudável, da eficácia da sociedade na garantia de implantação de políticas públicas voltadas para a qualidade da vida e dos serviços de saúde (BRASIL, 1997c, p. 255).

Nessa perspectiva, destaca-se a relevância dos assuntos que foram discutidos na sequência didática para a vida pessoal e social das pessoas, o que possibilitou o trabalho com problemas cotidianos relacionando-os com a ciência e a tecnologia tais como, saúde, higiene e meio ambiente.

Já os sentidos identificados abaixo demonstram uma preocupação com o uso de agrotóxicos e suas consequências.

Os agricultores podem diminuir um pouco a utilização de agrotóxicos para colaborar com essa situação e, assim, vai ser melhor para a saúde das pessoas e para eles, pois irá sobrar agrotóxico para usar somente quando precisar (E3A6).

Considerando os diversos riscos envolvidos no uso de agrotóxicos, tanto para o ambiente, quanto para a sociedade, este assunto adquire grande relevância para a formação 
cidadã. No contexto da unidade de análise acima, os sentidos identificados demonstram a adoção de um posicionamento ao relacionar a diminuição do uso de agrotóxicos com a qualidade da saúde das pessoas, fala que remete a uma atitude a ser tomada em relação a essa situação, mesmo que ainda incipiente aos processos de contaminação relativos ao meio ambiente. Sobre isso, é importante ressaltar que:

Além do lixo, dos esgotos e das queimadas, outras formas de poluição podem ser conhecidas. Os agrotóxicos - pesticidas, herbicidas e fungicidas — são substâncias que eliminam pragas agrícolas, mas misturadas ao solo e à água, são incorporadas aos vegetais e, consequentemente, aos animais e ao homem através das cadeias alimentares. São venenos que têm efeito cumulativo nos organismos vivos, causando danos irreversíveis à saúde. Por sua importância, esse assunto pode ser estudado, ainda que de forma abreviada, conhecendo-se a variedade e o uso dessas substâncias na agricultura, os problemas que acarretam para a saúde e técnicas alternativas no controle de pragas (BRASIL, 1997b, p. 71).

É essencial também que a escola proporcione a aprendizagem de pequenas ações ambientais que podem controlar os impactos da ação humana sobre a água. Entre estas ações, estão algumas técnicas viáveis que podem ser utilizadas na reposição de cobertura vegetal nativa como o plantio de mudas (BRASIL, 1998).

Nas unidades de análise: "As indústrias de papel podem plantar suas próprias árvores" (E3A24); "Plantar árvores perto da água" (E3A5), é possível verificar que A24 propõe uma ação alternativa de reflorestamento para diminuir o impacto ambiental das atividades realizadas pelas indústrias de papel e celulose, enquanto que A24 propôs o plantio de árvores perto da água já que neste momento da aula estavam sendo discutidas formas para minimizar o impacto das ações das pessoas sobre a água, demonstrando uma atitude que pode ser tomada em relação à proteção e renovação deste recurso.

Nesse sentido,

[...] os rápidos avanços tecnológicos viabilizaram formas de produção de bens com consequências indesejáveis que se agravam com igual rapidez. A exploração dos recursos naturais passou a ser feita de forma demasiadamente intensa, a ponto de pôr em risco a sua renovabilidade [...] (BRASIL, 1998).

Nessa perspectiva, investigar com os alunos as ferramentas e formas de controle dos impactos negativos provocados pela ação humana sobre a água, tais como a manutenção da mata ciliar e a redução do desmatamento são essenciais para o desenvolvimento de atitudes voltadas para a construção de uma sociedade sustentável. 


\begin{abstract}
Sabe-se que a formação de um mercado mundial instituiu relações que induziram à deterioração do ambiente e seria ingenuidade ignorar essa dimensão do problema. No entanto, a dura realidade econômica não justifica a destruição e a poluição, quando se sabe que há processos de produção mais adequados. Também não se justifica que, para poucos acumularem mais riquezas, muitos tenham de se submeter à destruição, ao dano à saúde e à pobreza. De fato, poluição não implica progresso: é antes, na maior parte das vezes, sinal de ignorância, ou egoísmo e descaso, bastante característicos daqueles que, apesar de possuírem conhecimento e consciência das implicações das suas atividades produtoras, continuam poluindo. Há que se considerar a questão ecológica-econômica-social como um problema a ser equacionado pela sociedade moderna (BRASIL, 1998, p. 184).
\end{abstract}

Entende-se que as atitudes são formadas por um inúmero conjunto de crenças e valores. Essas questões ganham importância à medida que podem influenciar diretamente as ações dos sujeitos, contribuindo para uma perspectiva crítica ou não. Diante do exposto, o que se observou nas atitudes propostas foram ações conservacionistas e pragmáticas. Portanto, na categoria desenvolvimento de atitudes, a dimensão crítica foi pouco evidenciada e deveria ter sido mais bem explorada e problematizada.

\title{
d) Desenvolvimento de habilidades
}

Na categoria desenvolvimento de habilidades, a análise e discussão dos resultados foram realizadas por meio do registro das atividades desenvolvidas, já que nesta categoria verifica-se o 'saber fazer'.

Capacidades consideradas simples como ler, localizar informações no texto, escrever e emitir opiniões a respeito de temas trabalhados na sala de aula são consideradas essenciais para o desenvolvimento de habilidades científicas. Isso proporciona a participação ativa dos alunos em diversas atividades, auxiliando no processo de tomada de decisão e contribuindo para uma formação cidadã. Portanto, pode-se dizer que as habilidades permitem que os alunos se comuniquem de modo apropriado, utilizando o conhecimento científico de forma adequada.

De acordo com Sasseron (2015), as habilidades estão vinculadas à construção de entendimento sobre temas das ciências e referem-se:

(a) ao trabalho com as informações e com os dados disponíveis, seja por meio da organização, da seriação e da classificação de informações; (b) ao levantamento e ao teste de hipóteses construídas que são realizados pelos estudantes; (c) ao estabelecimento de explicações sobre fenômenos em estudo, buscando justificativas para torná-las mais robustas e estabelecendo previsões delas advindas; e (d) ao uso de raciocínio lógico e raciocínio proporcional durante a investigação e a comunicação de ideias em situações de ensino e aprendizagem [...] (SASSERON, 2015, p. 57). 
Nas atividades demonstradas na Figura 4, foi realizada com os alunos a leitura individual e coletiva de dois textos: o primeiro aborda algumas consequências da falta de higiene nos recipientes de água mineral; o segundo trata do acidente ambiental ocorrido no ano 2000, com vazamento de óleo cru da Petrobras no mar de São Francisco do Sul, em Santa Catarina, que atingiu o Rio Barigui e o Rio Iguaçu, em Araucária. Em seguida, foi solicitado aos alunos que destacassem os principais trechos do texto, para que depois pudessem realizar uma síntese em forma de mapa conceitual.

Figura 4: Leitura e análise do texto sobre o acidente ambiental
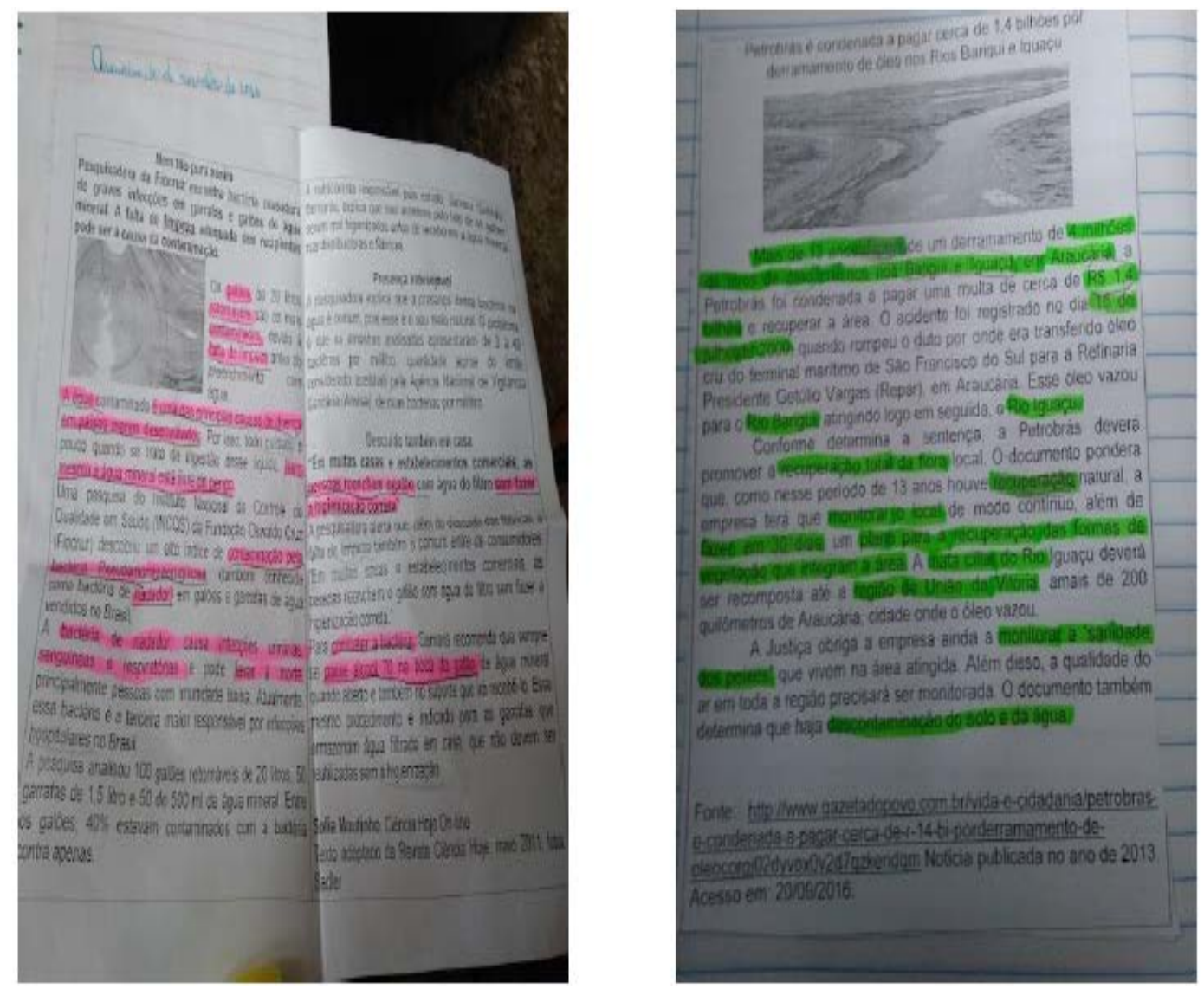

Fonte: Dados da Pesquisa

Por meio dessa atividade, os alunos desenvolveram habilidades de leitura, localizando informações no texto, capacidade esta que é fundamental para estabelecer relações a respeito do assunto abordado. 


\begin{abstract}
Sob orientação do professor, o aluno pode desenvolver observações e registros mais detalhados, buscar informações por meio de leitura em fontes diversas, organizá-las por meio da escrita e de outras formas de representação, de modo mais completo e elaborado que o aluno do primeiro ciclo. Ampliam-se, também, as possibilidades de estabelecer relações, o que permite trabalhar com maior variedade de informações, alargando a compreensão do mundo e das interações do homem com esse mundo. $\mathrm{O}$ aluno deste ciclo já pode compreender com maior e crescente desenvoltura explicações e descrições nos textos informativos que lê, ou naqueles lidos pelo professor, o que representa um ganho significativo em relação ao ciclo anterior (BRASIL, 1997b, p. 57).
\end{abstract}

Sasseron (2015) ainda destaca que tais habilidades devem ser avaliadas de acordo com o envolvimento do estudante evidenciado ao longo do trabalho pedagógico, como num processo, o qual inclui a discussão e resolução de problemas.

Nas atividades abaixo, os estudantes foram convidados a assistir um vídeo sobre as condições ambientais da fonte de água próxima da escola. Após assistirem ao vídeo, a professora deu as orientações necessárias e distribuiu um roteiro de investigação para que eles pudessem registrar o que foi observado. Por meio desta proposta investigativa, os alunos desenvolveram habilidades de observação, comparação, busca e registro de informações.

Figura 5: Atividade investigativa Parque Cachoeira e rio Iguaçu
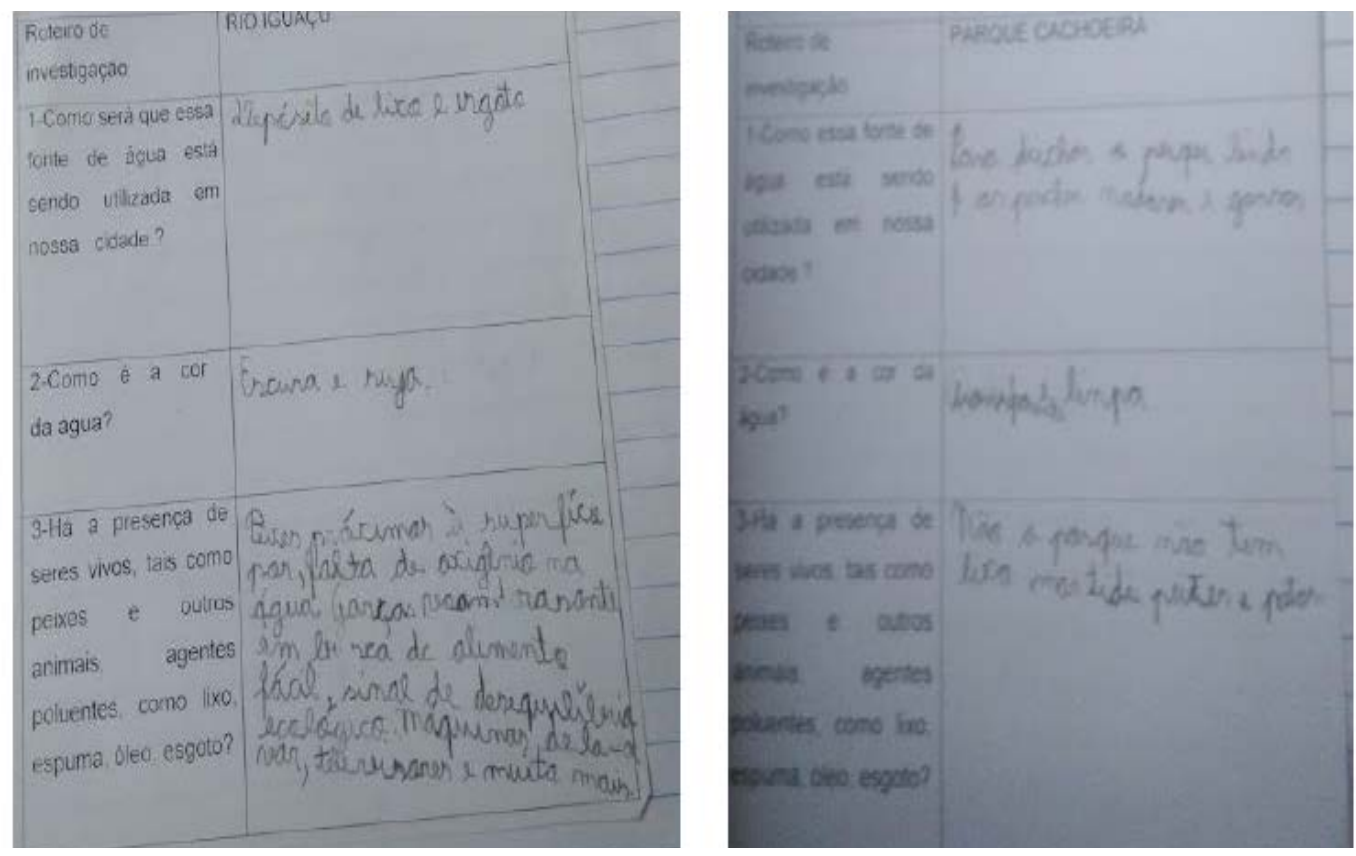

Fonte: Dados da Pesquisa. 
As práticas realizadas demonstraram uma relação geral com essas ações:

Comparação de diferentes ambientes naturais e construídos, investigando características comuns e diferentes, para verificar que todos os ambientes apresentam seres vivos, água, luz, calor, solo e outros componentes e fatos que se apresentam de modo distinto em cada ambiente; comparação dos modos com que diferentes seres vivos, no espaço e no tempo, realizam as funções de alimentação, sustentação, locomoção e reprodução, em relação às condições do ambiente em que vivem; busca e coleta de informações por meio de observação direta e indireta, experimentação, entrevistas, leitura de textos selecionados; organização e registro de informações por meio de desenhos, quadros, esquemas, listas e pequenos textos, sob orientação do professor (BRASIL, 1997b, p. 50).

Após a identificação das relações entre as orientações dos documentos oficiais com as atividades, cabe ressaltar que poucas habilidades foram localizadas nas ações desenvolvidas. Este fato reporta para a importância do desenvolvimento de ações que possam levar ao desenvolvimento dessas capacidades, inclusive nos relatos dos docentes.

Ressalta-se que, neste trabalho, a Base Nacional Comum Curricular (BNCC) não foi utilizada como parâmetro de reflexão e interpretação das unidades de análise, já que os objetos de conhecimentos e habilidades referentes à água e presentes na unidade temática 'Matéria e Energia' são abordados somente no $5 \square$ ano do Ensino Fundamental. Além disso, quando da realização da pesquisa a BNCC ainda não tinha sido aprovada pelo Conselho Nacional de Educação.

Ademais, a abordagem CTSA na BNCC é apresentada de forma superficial, pois não há qualquer diretriz mais específica para fundamentá-la, fato que não permite o desenvolvimento de reflexões e relações com as unidades de análise presentes neste trabalho. Há que se ressaltar também que, mesmo sendo o documento curricular oficial em nosso país atualmente, as propostas de ensino relacionadas à educação CTSA são tratadas apenas como uma competência a ser atingida no ensino (BRASIL, 2017). Sendo assim, os PCN e demais autores da área da Educação em Ciências tiveram papel relevante como referencial para a análise dos dados.

Por outro lado, Sasseron (2018) destaca que tais ponderações sobre a BNCC precisam ser analisadas com cautela, já que seus fundamentos teóricos não expressam o ensino que será materializado nas escolas. O professor poderá utilizar sua autonomia para desenvolver outras ações e estratégias para conciliar a proposta do Ministério da Educação com a realidade de sua sala de aula e de seus estudantes. 
Cabe ressaltar que as transformações que o ensino de ciências vem sofrendo em todo o mundo nas últimas décadas demonstram uma necessidade de mudança no processo de ensino, no qual a aprendizagem dos conteúdos inclui práticas científicas e epistêmicas de participação ativa e intelectual dos estudantes. Isso poderá contribuir junto ao ensino das demais disciplinas e áreas de conhecimento, para que os estudantes tenham uma visão mais ampla sobre a humanidade, como também os capacite a tomar decisões de modo mais consciente e crítico.

Sasseron (2015) ressalta ainda que o entendimento das relações entre ciência, tecnologia, sociedade e ambiente permitem essa visão mais completa e atualizada da ciência, além de conexões que impactam a produção de conhecimento, o que revela a complexidade existente nas relações que envolvem o homem e a natureza.

Nesse sentido, a aquisição desses conhecimentos é uma condição para alfabetizar cientificamente os alunos, preparando os mesmos para o exercício da cidadania.

\section{Considerações finais}

Este estudo objetivou analisar como a abordagem CTSA, desenvolvida por meio de uma sequência didática, pode contribuir para o desenvolvimento de conhecimentos, valores, atitudes e habilidade nas aulas de Ciências nos anos iniciais.

Considerando o contexto da pesquisa, os dados apresentados podem não ser muito expressivos do ponto de vista quantitativo, mas demonstram ser suficientes, se forem considerados o tema abordado, o nível dos alunos e a atuação da professora.

Nessa perspectiva, é importante ressaltar que a docente não conhecia as temáticas apresentadas na formação, portanto, os conhecimentos teóricos e pedagógicos que possuía sobre os assuntos abordados eram muito incipientes.

Apesar disso, o estudo dos temas apresentou repercussões positivas, já que a profissional teve que sair da 'zona de conforto' na qual se encontrava, sendo de certo modo desafiada em seus conhecimentos prévios. O curso mexeu com posturas e comportamentos docentes já consolidados que, anteriormente, pareciam seguros e estabilizados.

Embora a professora tenha demonstrado bastante interesse nos encontros, isto se mostrou insuficiente no momento da intervenção pedagógica, já que não foi fácil colocar em prática tudo aquilo que havia sido discutido, principalmente no que se refere à construção dos conhecimentos exigida na metodologia dos Três Momentos Pedagógicos e no desenvolvimento de relações que envolviam a Educação CTSA. 
Esses fatos evidenciaram a necessidade de modificação de posturas epistemológicas, para que a docente conseguisse se adequar e desenvolver um trabalho nessa abordagem, fato que foi determinante na condução da prática pedagógica.

Para conseguir resultados mais efetivos na implementação da sequência didática, seria necessário mais tempo de formação e acompanhamento constante, que incluísse reflexões sobre a prática e encontros direcionados para que a docente pudesse demonstrar suas inseguranças e, ao mesmo tempo, adquirir mais confiança na proposta pedagógica que lhe foi apresentada.

Contudo, pôde-se notar boa vontade nas ações da professora, que inclusive relegou outras obrigações de seu cotidiano para poder se reunir com a pesquisadora e esclarecer dúvidas sobre o andamento da sequência didática, e assim, melhorar a qualidade do seu trabalho. Mesmo que num período de transição para a perspectiva crítica, foi possível notar que a docente passou a atuar mais na construção dos conhecimentos discentes.

Em relação à participação dos alunos, é importante destacar o fortalecimento do diálogo e certa autonomia no processo de aprendizagem. A estruturação das aulas a partir das etapas propostas pelos Três Momentos Pedagógicos trouxe uma nova dinâmica e motivou os alunos para a participação. No decorrer das aulas, vários estudantes envolveram-se nas discussões realizadas, compartilhando exemplos de sua realidade, demonstrando que o conhecimento estava sendo construído.

Embora as propostas e relatos dos discentes ainda estejam numa perspectiva pragmática e conservacionista, é necessário esclarecer que, para esse nível de ensino não era esperado que os alunos apresentassem um ponto de vista crítico, pois conforme evidenciado anteriormente, isso se desenvolve num processo.

Para avançar rumo a esse objetivo, é necessário, desde o início da trajetória escolar, possibilitar situações de ensino para que os estudantes possam desenvolver uma concepção crítica e humanista de educação, que leve a questionar a realidade que está posta em seus diversos aspectos.

Sendo assim, investir na formação continuada do professor continua sendo uma demanda muito atual. Esta necessidade também se justifica pelos dados obtidos na pesquisa, que mostraram que os três encontros do programa que foram direcionados para o ensino de ciências, propiciaram avanços significativos na prática da docente.

A análise dos referenciais teóricos demonstrou que a abordagem CTSA representa um caminho viável para ampliar os mecanismos de participação discente e 
potencializar o processo de tomada de decisão, elementos que integram a base de uma formação cidadã.

Nessa perspectiva, o papel de promoção da cidadania não pode ser visto somente como responsabilidade de um ou outro professor, mas sim de toda uma comunidade escolar; pois instrumentalizar para a mudança também é dever dos gestores educacionais e dos sistemas de ensino.

Portanto, as dificuldades relatadas neste trabalho também precisam ser compreendidas do ponto de vista da pesquisa, do contexto histórico em que a mesma se apresenta, do momento atual de desvalorização do professor, das dificuldades formativas do docente e dos problemas complexos que fazem com que as intenções nem sempre estejam no mesmo nível das ações.

Ademais, é preciso reconhecer que a discussão sobre CTSA em nosso país ainda não passou do nível acadêmico. Isto talvez ocorra porque ainda não se conseguiu atingir um nível político que possibilitasse mudanças no currículo e nas políticas públicas, como as ocorridas em outros países.

Cabe a nós, professores, disseminar práticas de ensino que possam mudar essa realidade, atuando de forma a combater comportamentos passivos e resistentes para que mais docentes se sintam desafiados e instigados a contemplar a abordagem das relações entre Ciência, Tecnologia, Sociedade e Ambiente em suas aulas.

\section{The STSE approach in the early years of elementary school: contributions to the exercise of citizenship}

\section{Abstract}

In order to make science education more meaningful for students' lives and to contemplate broad aspects, such as citizen education and the relations between science, technology, society and the environment, advocates a teaching approach that focuses on the development of interrelations between these elements. Therefore, the purpose of this paper is to present the results of a study that analyzed how the STSE approach, developed through a didactic sequence, can contribute to the development of knowledge, values, attitudes and abilities. The didactic sequence was developed with 24 students of a municipal school in Araucária-PR, characterizing itself as a research of pedagogical intervention of qualitative nature. The data indicate that the teaching proposal allowed the students to participate actively in the process of knowledge construction. Through the discussions, knowledge, values, attitudes and skills were developed that are essential elements for the exercise of citizenship.

Keywords: Science Teaching, didactic sequence, STSE Approach, citizenship. 
AIKENHEAD, G. S. (1994). What is STS science teaching? In: SOLOMON, J., AIKENHEAD, G. STS education: international perspectives on reform. New York: Teachers College Press, p. 47-59.

AULER, D. Articulação entre pressupostos do educador Paulo Freire e do movimento CTS: novos caminhos para a educação em ciências. Revista Contexto e Educação, Ijuí, v. 22, n. 77, p. 167188, 2007.

BYBEE, R. W. (1987). Science education and the science-technology-society (STS) theme. Science Education, v. 71, n. 5, p. 667-683.

BRASIL. Ministério da Educação (MEC), Secretaria de Educação Fundamental (SEF). Parâmetros curriculares nacionais: apresentação dos temas transversais, ética. Brasília: MEC/ SEF, 1997a.

BRASIL. Ministério da Educação (MEC), Secretaria de Educação Fundamental (SEF). Parâmetros curriculares nacionais: ciências naturais. Brasília: MEC/SEF, 1997b.

BRASIL. Ministério da Educação (MEC), Secretaria de Educação Fundamental (SEF). Parâmetros curriculares nacionais: apresentação dos temas transversais, saúde. Brasília: MEC/ SEF, 1997c.

BRASIL. Ministério da Educação (MEC), Secretaria de Educação Fundamental. Parâmetros curriculares nacionais: apresentação dos temas transversais, meio ambiente. Brasília: MEC/ SEF, 1998.

BRASIL. Ministério da Educação, Ministério do Meio Ambiente e Instituto Brasileiro de Defesa do Consumidor. Manual de educação para o consumo sustentável. Brasília, 2005.

BRASIL. Ministério da Educação (MEC), Secretaria de Educação Fundamental (SEF). Base Nacional Comum Curricular: Educação Infantil, Ensino Fundamental e Ensino Médio. Brasília: MEC/SEF, 2017.

CARRERAS, L. L. et al. Como educar integrando valores: materiais, textos, recursos e técnicas. São Paulo: Edições Loyola, 2006.

CARVALHO, A. M. P.; VANNUCCHI, A.I.; BARROS, M. A.; GONÇALVES, M. E. R.; REY, R. C. Ciências no Ensino Fundamental: o conhecimento físico. São Paulo: Scipione, 1998.

CARVALHO, I.C.M. Educação Ambiental Crítica: nomes e endereçamentos da educação. In: LAYRARGUES, P.P. Identidades da Educação Ambiental brasileira. Brasília: MMA. Diretoria de Educação Ambiental, 2004. p. 13-24.

CARRERAS, L.L. et al. Como educar integrando valores: materiais, textos, recursos e técnicas. São Paulo: Edições Loyola, 2006.

CASTRO, R. S. et al. CTSA: uma abordagem para enfrentar a complexidade do mundo contemporâneo. In: ENCONTRO NACIONAL DE PESQUISA EM EDUCAÇÃO EM CIÊNCIAS. VI. Anais... Florianópolis. 2007.

CZAPSKI, S. Mudanças ambientais globais. Pensar + agir na escola e na comunidade. Secretaria de Educação Continuada, Alfabetização e Diversidade (Secad). MEC. 2008.

DAMIANI, M. F. et al. Discutindo pesquisas do tipo intervenção pedagógica. Cadernos de Educação. FaE/PPGE/UFPel. Mai/agosto 2013. 
DAMIANI, M.F. Sobre Pesquisas do Tipo Intervenção. In: ENCONTRO NACIONAL DE DIDÁTICA E PRÁTICAS DE ENSINO. XVI. Anais... Campinas. 2012.

DELIZOICOV, D.; ANGOTTI, J. A.; PERNAMBUCO, M. M. Ensino de ciências: fundamentos e métodos. São Paulo: Cortez, 2011.

DIEGUES, A. C. S. Desenvolvimento sustentável ou sociedades sustentáveis: da crítica dos modelos aos novos paradigmas. Revista São Paulo em Perspectiva, São Paulo, v. 6, 1 e 2, p. 22-29, jan./jun. 1992.

FABRI, F. O ensino de ciências nos anos iniciais do ensino fundamental sob a ótica CTS: uma proposta de trabalho diante dos artefatos tecnológicos que norteiam o cotidiano dos alunos. 2011. Dissertação (Mestrado Profissionalizante em Ensino de Ciência e Tecnologia) - Universidade Tecnológica Federal do Paraná, Ponta Grossa, 2011.

FABRI, F. Formação continuada para o ensino de ciências na perspectiva ciência, tecnologia e sociedade (CTS): contribuições para professores dos anos iniciais. 2017. Tese (Doutorado em Ensino e Ciência e Tecnologia) - Universidade Tecnológica Federal do Paraná, Ponta Grossa, 2017.

FERST, E. M. A abordagem CTS no ensino de ciências naturais: possibilidades de inserção nos anos iniciais do Ensino Fundamental. Revista EDUCAmazônia - Educação Sociedade e Meio Ambiente, Humaitá, v. XI, n. 2, p. 276-299, dez. 2013.

FERST, E. M. Relação CTS no contexto da formação inicial de professores no curso de pedagogia 2016. Tese (Doutorado em Educação em Ciências e Matemática) - Universidade do Estado do Amazonas, Manaus, 2016.

FERREIRA, L. S. Uma reflexão sobre a prática educativa nos anos iniciais com enfoque CTS: pelo desenvolvimento da profissionalidade docente. 2016. Dissertação (Mestrado em Educação Científica e Formação de Professores) - Universidade Estadual do Sudoeste da Bahia, Jequié, 2016.

GONZÁLEZ GAUDIANO, É.; KATRA, L. F. Valores e Educação Ambiental: aproximações teóricas em um campo em contínua construção. Revista Educação \& Realidade, Porto Alegre, v. 34, n. 3, p.41-65, 2009.

GRYNSZPAN, D. Educação Ambiental em uma Perspectiva CTSA: orientações teóricometodológicas para práticas investigativas. In: Pedrini, A. e Saito, C. (Orgs.). Paradigmas Metodológicos em Educação Ambiental. Rio de Janeiro: Vozes, 2014.

INVERNIZZI, N.; FRAGA, L. Estado da arte na educação em ciência, tecnologia, sociedade e ambiente no Brasil. Revista Ciência \& Ensino, Piracicaba, v. 1, número especial, nov. 2007.

MAESTRELLI, S. G.; LORENZETTI, L. As relações CTSA nos anos iniciais do Ensino Fundamental: analisando a produção acadêmica e os livros didáticos. Revista Amazônica, Belém, v. 13, n, 26, p. 5-21, 2017.

MARTINS, I. P.; PAIXÃO, M. D. F. Perspectivas atuais Ciência-Tecnologia-Sociedade no ensino e na investigação em educação em ciência. In: SANTOS, W. L. P. dos; AULER, D. (Orgs). CTS e educação Científica: desafios, tendências e resultados de pesquisa. Brasília-DF: Editora UnB, 2011. p. 135-160.

NIGRO, R.G. Projeto Ápis: Ciências. 2. ed. São Paulo: Ática, 2015. 
NOVAES, T. H.; FRAGA, L. Por um novo desenvolvimento na América Latina. In: DAGNINO, R. (Org.). Estudos Sociais da Ciência E Tecnologia \& Política de Ciência E Tecnologia: Abordagens Alternativas Para Uma Nova América Latina. Campina Grande: EDUEPB, 2010. p. 155- 188 .

MOTA, J. C. G. A perspectiva CTS no currículo do ensino fundamental I de uma escola da rede federal. 2017. Dissertação (Mestrado Profissional em Ensino de Ciências) - Instituto Federal de Educação, Ciência e Tecnologia do Rio de Janeiro, Nilópolis, 2017.

OLIVEIRA, E. S. de. A educação ciência-tecnologia-sociedade (CTS) no contexto dos anos iniciais do ensino fundamental. 2017. Tese (Doutorado em Educação em Ciências e Matemática) - Universidade do Estado do Amazonas, Manaus, 2017.

RATTNER, H. (Org.). Brasil no limiar do século XXI: Alternativas para a construção de uma sociedade sustentável. São Paulo: EDUSP, 2000.

RODRIGUES, M. F. Produção de histórias infantis para os anos iniciais do ensino fundamental: um recurso didático numa visão CTS. 2017. Dissertação (Mestrado em Ensino) - Instituto Federal de Educação Ciência e Tecnologia do Rio Grande do Norte, Mossoró, 2017.

SANTOS, W. L. P. Contextualização no ensino de ciências por meio de temas CTS em uma perspectiva crítica. Revista Ciência \& Ensino, Piracicaba, v. 1, número especial, p. 1-12, 2007.

SANTOS, W. L. P. Significados da educação científica com enfoque CTS. In: SANTOS, W.L.P.; AULER, D. (Orgs). CTS e educação Científica: desafios, tendências e resultados de pesquisa. Brasília: Editora UnB, 2011. p. 21-47.

SANTOS, W. L. P.; MORTIMER, E. F. Uma análise dos pressupostos teóricos da abordagem C-T-S (Ciência-Tecnologia-Sociedade) no contexto da educação Brasileira. Revista Ensaio - Pesquisa em Educação em Ciências, Belo Horizonte, v. 2, n. 2, p. 1-23, dez. 2002.

SASSERON, L. H.; CARVALHO, A. M. P. Ensino por CTSA: almejando a Alfabetização Científica no Ensino Fundamental. In: ENCONTRO NACIONAL DE PESQUISA EM EDUCAÇÃO EM CIÊNCIAS. VI. Anais... Florianópolis. 2007.

SASSERON, L. H.; CARVALHO, A. M. P. Almejando a alfabetização científica no ensino fundamental: a proposição de indicadores do processo. Revista Investigações em Ciências, Porto Alegre, v. 13, n. 3, p. 333-352, 2008.

SASSERON, L. H. CTSA no ensino fundamental e a argumentação entre alunos e professora. Enseñanza de las ciências, VIII Congreso Internacional sobre Investigación en Didáctica de las Ciencias, n. extra, Barcelona, p. 28-32, jul. 2009.

SASSERON, L. H. Alfabetização científica, ensino por investigação e argumentação: relações entre ciências da natureza e escola. Revista Ensaio, Belo Horizonte, 17(n. especial), p. 49-67, nov. 2015.

SASSERON, L. H. Ensino de ciências por investigação e o desenvolvimento de práticas: uma mirada para a Base Nacional Comum Curricular. Revista Brasileira de Pesquisa em Educação em Ciências, Belo Horizonte, v. 18, n. 3, p. 1061-1085, dez. 2018.

SCOTTO, G.; CARVALHO, I.C.M.; GUIMARÃES, L.B. Desenvolvimento Sustentável. Petrópolis, RJ: Vozes, 2007.

SILVA, V. C.; VIDEIRA, A. A. P. Como as ciências morrem? Os ataques ao conhecimento na era da pós-verdade. Caderno Brasileiro de Ensino de Física, Florianópolis, v. 37, n. 3, p. 10411073, dez. 2020. 
VASCONCELLOS, E. S.; SANTOS, W. L. P. Educação ambiental em aulas de química: refletindo sobre a prática a partir de concepções de alunos sobre meio ambiente e educação ambiental. In: ENCONTRO NACIONAL DE PESQUISA EM EDUCAÇÃO EM CIÊNCIAS. VI. Florianópolis. Anais... 2007.

VIECHENESKI, J. P. Sequência didática para o ensino de ciências nos anos iniciais: subsídios teórico-práticos para a iniciação à alfabetização científica. 2013. Dissertação (Mestrado Profissional em Ensino de Ciência e Tecnologia_ - Universidade Tecnológica Federal do Paraná, Ponta Grossa, 2013.

VIECHENESKI, J. P. Relações entre ciência, tecnologia e sociedade em livros didáticos integrados de ciências humanas e da natureza para os anos iniciais do ensino fundamental. 2019. Tese (Doutorado em Ensino de Ciência e Tecnologia) - Universidade Tecnológica Federal do Paraná, Ponta Grossa, 2019.

VICTORINO, C. J. A. Planeta Água morrendo de sede: uma visão analítica na metodologia do uso e abuso dos recursos hídricos. Porto Alegre: EDIPUCRS, 2007.

VIEIRA, A. R. Cadernos de Educação Ambiental Água para a vida, água para todos: Livro das Águas. Brasília: WWF- Brasil, 2006.

VILCHES, A. GIL-PÉREZ, D. PRAIA, J. De CTS a CTSA: educação por um futuro sustentável. In: SANTOS, W. L. P. dos. AULER, D. (Orgs). CTS e educação Científica: desafios, tendências e resultados de pesquisa. Brasília: Editora UnB, 2011. p. 161-184.

VON LINSINGEN, I.; PEREIRA, L. T. V.; BAZZO, W. A. Introdução aos Estudos CTS (Ciência, Tecnologia e Sociedade). Cadernos de Ibero-América, n.1, ed. OEI, 2003.

ZAIONS, J.R.M. A educação ambiental nos cursos de formação de docentes, na modalidade normal, em nível médio, e a disseminação da temática ambiental nos anos iniciais. 231 f. Dissertação (Mestrado em Educação em Ciências e em Matemática). Universidade Federal do Paraná, Curitiba, 2017. 